
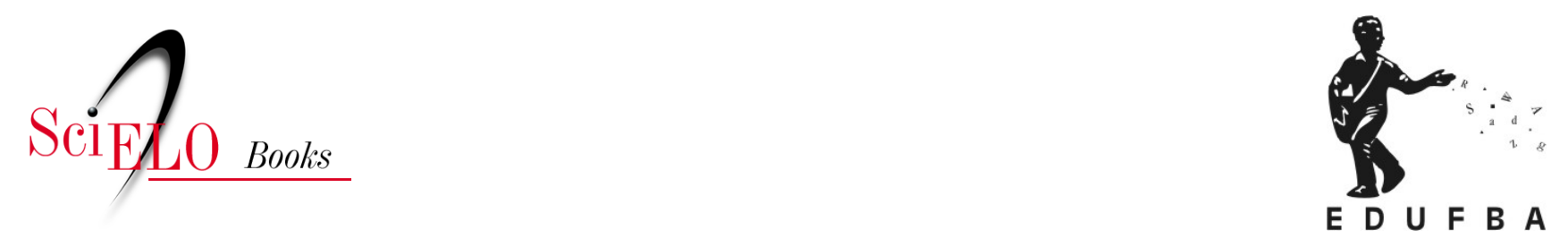

\title{
O Concílio de Trento e as Constituições Primeiras do Arcebispado da Bahia "programa" da arte sacra no Brasil
}

\author{
Maria Helena Ochi Flexor
}

\section{SciELO Books / SciELO Livros / SciELO Libros}

FLEXOR, M.H.O. O Concílio de Trento e as Constituições Primeiras do Arcebispado da Bahia: "programa" da arte sacra no Brasil. In: HERNÁNDEZ, M.H.O., and LINS, E.Á., eds. Iconografia: pesquisa e aplicação em estudos de Artes Visuais, Arquitetura e Design [online]. Salvador: EDUFBA, 2016, pp. 206-251. ISBN: 978-85-232-1861-4. https://doi.org/10.7476/9788523218614.0013.

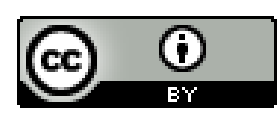

All the contents of this work, except where otherwise noted, is licensed under a Creative Commons Attribution $\underline{4.0 \text { International license. }}$

Todo o conteúdo deste trabalho, exceto quando houver ressalva, é publicado sob a licença $\underline{\text { Creative Commons }}$ Atribição 4.0. 


\section{o concílio de Trento e as Constituiçóes}

Primeiras do

Arcebispado da

Bahia: "programa"

da arquitetura e arte

sacras no Brasil

Maria Helena Ochi Flexor 


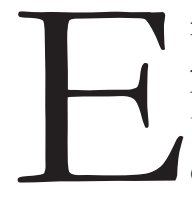

m 1564, o Papa Pio IV confirmou os decretos conciliares tridentinos pela bula Benedictus Deo e, no mesmo ano, o Rei português, D. Sebastião, através de seu cardeal, D. Henrique, mandava "dar todo o favor e ajuda [...] para a execução dos decretos do concílio". (REYCEND, 1786) Aos poucos, os arcebispos e bispos portugueses começaram a proceder às convocações para realizar reuniões sinodais. ${ }^{1}$ Todos obedeciam à sessão XXV, do Concílio de Trento, exortando aos congregados das igrejas a observar tudo o que se havia disposto, fazendo, para isso, profissão de fé. Essa sessão reafirmou ou deu origem às devoções, formas de representação, de religiosidade e comportamentos e, especialmente, todas as expressões nas artes - como decoração e iconografia, apregoadas e adotadas a partir desse Concílio -, na arquitetura, escultura, talha, pintura, ourivesaria, mobiliário, azulejaria, afresco, entre outras realizações.

1 Assim, datam de 1565 as Constituições Synodaes do Arcebispado de Évora; as Constituições do arcebispado de Lisboa assi as antigas como as extravagantes primeyras e segundas, de 1588; as Constitvições Synodaes do Bispado do Porto, de 1585; as Constituições Synodaes do Bispado de Coimbra, de 1639 (impressas em 1691); as Constituições Synodaes do Arcebispado de Braga, publicadas de um total de 36 reuniões sinodais. As disposições desses sínodos, mutatis mutandis, são as mesmas das Constituições da Bahia. 
Para o Brasil, foram feitas as Constituições Primeiras do Arcebispado da Bahia, como uma grande defasagem em relação às congêneres lusas - da Metrópole e domínios -, e, principalmente, quanto ao Concílio de Trento (1545-1563).² Devia haver um exemplar das Constituições na Sé Catedral, Cabido do Arcebispado, igrejas paroquiais, curadas e na Relação Eclesiástica para uso do provisor, vigários da vara, advogados, meirinho geral, escrivão da Câmara Eclesiástica, visitadores, comprados às custas da fábrica das igrejas. Desde que aprovadas e publicadas, as determinações das Constituições deveriam ser lidas publicamente, em especial nas missas, para que os fiéis tivessem conhecimento de seu conteúdo, o que, de um lado, deu instrumentos legais à Inquisição e, do outro, uniformizou os procedimentos lusos, tanto nas instituições religiosas portuguesas, quanto em suas conquistas, no Ocidente e no Oriente. Até que as Constituições baianas fossem elaboradas, impressas e divulgadas, a Bahia e o Brasil se serviram das Constituições de Lisboa. ${ }^{3}$

Chegando em 1702 e visitando todas as paróquias, o $5^{\circ}$ Arcebispo, D. Sebastião Monteiro da Vide, sentiu a necessidade de proceder à "direção dos costumes, extirpação dos vícios, e abusos, moderação dos crimes, e reta administração da justiça [...]". ${ }^{4}$ (CONSTITUIÇÕES..., 1853, p. XIX-XX) Cuidando da vida pastoral da Bahia, procurou "o aproveitamento espiritual e temporal, e a quietação de nossos súditos" (CONSTITUIÇÕES..., 1853, p. XIX-XX) e tomou as providências necessárias para recompor a sociedade cristã, segundo as novas diretrizes. Promoveu, então, a melhor forma de disciplinar a sociedade, alegando que:

[...] considerando nós, que as ditas Constituições de Lisboa se não podiam em muitas coisas acomodar a esta tão diversa região, resultando dai alguns abusos no culto Divino, administração da justiça, vida, e costumes de nossos súditos: e querendo satisfazer ao nosso Pastoral oficio, e com oportunos remédios tão grandes danos, fizemos, e ordenamos novas Constituições, e Regimento do nosso auditorio, e dos oficiais de nossa justiça [...]. (CONSTITUIÇÕES..., 1853, p. XIX-XX)

2 Consta que, em 1605, o $4^{\circ}$ Bispo da Bahia, D. Constantino Barradas, intentou fazer as Constituições, mandando guardar as normas portuguesas mais antigas, mas, como não foram impressas, "viciaram-se" (CONSTITUIÇÕES..., 1853, p. XII) e ficaram sem cumprimento.

3 Entre 1533 e 1551, a Bahia esteve ligada à Arquidiocese de Funchal. Sendo esta extinta nessa data, criou-se a Diocese de São Salvador da Bahia, sufragânea à Sé de Lisboa, nesse mesmo ano de 1551. Assim permaneceu até ser elevada à Sede Metropolitana e Primacial do Brasil, em 1676, sem contar ainda com suas Constituições próprias.

4 Transcrições modernizadas. 
As Constituições elaboradas pelo Arcebispo só foram aprovadas em 1707, publicadas em Pastoral de 21 de julho, depois de aprovadas pelo Sínodo Diocesano, findo em 14 do mesmo mês e ano. Só foram impressas em 1719. Seguiam os modelos, especialmente de Lisboa e do Porto, ${ }^{5}$ adaptando-se às normas tridentinas. Além disso, como foi destacado pelo Arcebispo, cuidavam dos usos e costumes da Arquidiocese, especialmente considerando os componentes da sociedade na América Portuguesa: o português, o índio e o negro e as condições específicas da Bahia e do Brasil. Isso explica, por exemplo, as consultas feitas, para a composição das Constituições, às obras de Juan de Solórzano y Pereira $(1629,1639,1996)$ e Jorge Benci (1705). O primeiro era um jurista, herdeiro dos ensinamentos de Salamanca, Ouvidor das Audiências do Reino do Peru, incluiu os indígenas americanos numa obra de direito, sendo autor da "Política indiana" (SOLÓRZANO Y PEREIRA, 1996), e o segundo autor, jesuíta, tratou e escreveu sobre a "educação dos escravos". ${ }^{6}$

No conjunto, as Constituições regulavam toda a vida da sociedade - tendo, muitas vezes, direito de vida e de morte sobre ela ${ }^{7}$-, mas a proposta deste artigo é apontá-las como programa e arquitetura, bem como as suas relações com as devoções e expressões artísticas ligadas à igreja. Apesar disso, no entanto, deve-se ressaltar a proclamação, através de suas normas, da imunidade dos eclesiásticos, determinando sua própria jurisdição, interditando citações ou demandas por parte dos juízes seculares, ficando isentos de tributos, gozando de privilégios, entre outras características.

Tudo que se referia à igreja estava sob a jurisdição eclesiástica e do Rei, por força do Padroado. De acordo com o Direito Canônico, cabia ao bispo ou arcebispo a instituição das igrejas e seus benefícios, porém:

5 E ainda, no Direito Canônico, Concílios, Decretos e Bulas dos Papas, opiniões e doutrinas dos Santos Padres, Doutores e Praxistas, além das Ordenações do Reino. (CONSTITUIÇÕES..., 1853, p. VI)

6 BENCÍ, Jorge. Economia christaã dos senhores do governo dos escravos; deduzida das palavras do capítulo 33 do eclesiástico panis (disciplina), e opus (servo): reduzida a quatro discursos morais pelo padre Jorge Benci de Arimino, da Companhia de Jesus, Missionário da Província da Bahia, e “[...] offerecida a Alteza Real do Sereniss. Granduque de Toscana pelo Padre Antonio Maria Bonucci da mesma Companhia”. Roma: Officina de Antonio de Rossina, 1705.

7 Segundo Ildefonso Xavier Ferreira, que escreveu o prólogo da edição das Constituições de 1853, elas foram feitas "em tempo, que um Governo absoluto reinava em Portugal; o privilegio do canon existia em toda a sua extensão; o foro mixto era uma regalia dos Prelados; o poder de impor multas, de enviar ao aljube os Sacerdotes, e mesmo aos fiéis seculares, de degredar, ou desterrar a qualquer para a Africa, ou para fora do pais estava ao arbítrio do Ordinario Eclesiástico; finalmente o horrível Tribunal da Inquisição trabalhava com eficacia no Reino Portugues. Debaixo deste ponto de vista foram feitas as Constituições do Arcebispado da Bahia". (CONSTITUIÇÕES..., 1853, p. V) E vigoraram, pelo menos, até a promulgação da Constituição Política do Império, em 1824, e do Código de Processo Civil, de 1832. 
[...] esta regra se limita nas igrejas, e beneficios que são do Padroado, e com todas as deste Arcebispado, e mais conquistas o sejam por pertencerem à Ordem e Cavalaria de nosso Senhor Jesus Cristo, de que Sua Majestade é Grão Mestre, e perpetuo Administrador não incumbe aos Ordinários Ultramarinos, mais que a colação, e confirmação dos clérigos que Sua Majestade apresenta. (CONSTITUIÇÕES..., 1719, p. 210)

O Rei, no entanto, deixava aos bispos e arcebispos a colação e confirmação dos clérigos, mas os nomes eram propostos por Sua Majestade, através de Provisões Régias. Só com este documento, o candidato - escolhido através de concurso realizado após edital - era confirmado e colado na forma do Direito Canônico. Cada posto da hierarquia exigia uma série de requisitos diferenciados, conforme o cargo. (CONSTITUIÇÕES..., 1719)

O Concílio de Trento reafirmou a imunidade da igreja e de seus componentes e, em função do Direito Canônico, exortou aos reis e príncipes que cumprissem essa obrigação - para servir de exemplo aos súditos e vassalos -, imitando seus antecessores, “com Sua Real autoridade e magnificência, não só edificarão muitas igrejas", além de recomendar o aumento de outras "com suas liberais doações, e dádivas", mas, sobretudo, precisavam ter cuidado e zelo em defender e fazer guardar a sua imunidade. As Constituições pediam ao Rei que mandasse examinar, reformar tudo o que neste "Estado do Brasil houver contra ela", além da imunidade, obedecendo à jurisdição eclesiástica. (CONSTITUIÇÕES..., 1719, p. 248-249)

Quanto à arquitetura religiosa, as normas determinavam:

Ainda que é coisa muito pia, e louvável edificarem-se capelas em honra, e louvor de Deus nosso Senhor, da Virgem Senhora nossa, e dos Santos, porque com isso se excita, e afervora a devoção dos fiéis, e segue a utilidade de haver nas grandes, e dilatadas paroquias lugares decentes, em que comodamente se possa celebrar; como convem muito que se edifiquem em tal consideração que, erigindo-se para ser Casa de Oração, e devoção, não sejam de escândalos pela pouca decência, e ornato delas, ordenamos, e mandamos, que querendo algumas pessoas em nosso Arcebispado fundar capela de novo, nos dem primeiro conta por petição, e achando nós por vestoria, e informação, que mandaremos fazer, que o lugar é decente, e que se obrigam a fazê-la de pedra, e cal, e não somente de madeira, ou de barro, assinando-lhe dote competente ao menos de seis mil réis cada ano para sua fabrica, reparação, e ornamentos, lhe conce- 
deremos licença, fazendo-se de tudo autos, e escrituras, que se guardam no Cartorio da nossa Câmera. (CONSTITUIÇÕES..., 1719, p. 167)

Assim, nenhum edifício religioso - igreja, capela, ermida, colégio ou mosteiro - poderia ser construído, ou reedificado, depois de caído e arruinado sem ser de acordo com o Direito Canônico - e, segundo o Concílio de Trento, ou "à romana", sem autorização do Arcebispado, sob pena de sofrer excomunhão maior: 50 cruzados, destinados para as despesas da igreja e para o "acusador" do ser derrubadas as obras já feitas. Mas se as capelas e ermidas estivessem muito velhas e arruinadas e com falta total de ornamentos, sem renda para sua fábrica, ou, ainda, se estivessem em lugar ermo e despovoado, expostas a "indecências", os visitadores deveriam se informar, registrando os autos e sumários, relatando o estado de ruína da construção. Não havendo quem pudesse recuperá-las, seriam "derrubadas e profanadas". Se existissem imagens, recomendava-se que fossem levadas para a igreja paroquial respectiva. (CONSTITUIÇÕES..., 1719, p. 168)

Conforme o Direito Canônico, as Igrejas se devem fundar e edificar em lugares decentes, e acomodados. Pelo que mandamos, que havendo-se de edificar de novo alguma Igreja Paroquial em nosso Arcebispado, se edifique em sitio alto, e lugar decente livre de umidade, e desviado, quanto for possível, de lugares imundos e sórdidos, e de casas particulares, e de outras paredes, em distancia que possam andar as Procissões ao redor delas, e que se faça em tal proporção, que não somente seja capaz dos fregueses todos, mas ainda de mais gente de fora, quando concorrer as festas, e se edifique em lugar povoado, onde estiver o maior número de fregueses. (CONSTITUIÇÕES..., 1719, p. 165)

As autoridades eclesiásticas, depois de visitarem o terreno, se encarregavam de mandar "levantar Cruz no lugar, aonde houver de estar a Capela maior, e se demarcará o âmbito da igreja, e adro dela". (CONSTITUIÇÕES..., 1719, p. 165, 1853, p. 251-252) As construções feitas por iniciativa real ou eclesiástica, bem como aquelas criadas por particulares, com licença do Ordinário do Arcebispado, eram obrigadas a verificar que as fundações não fossem postas em lugares ermos e despovoados ou alagados. A recomendação básica, da apresentação especialmente, das ermidas ou capelas era estarem limpas, e a chave deveria ser entregue a uma pessoa devota, que cuidasse de abri-la e fechá-la, e ter cuidado com sua limpeza. (CONSTITUIÇÕES..., 1719)

8 A figura do acusador já era institucionalizada, junto à justiça secular, desde a fundação da cidade do Salvador, através das posturas dos Senados da Câmara e das Ordenações Filipinas, e não fugia à regra, à Justiça Eclesiástica. Foi sujeito de destaque durante a vigência da Inquisição. 
As Constituições baianas não discriminavam os detalhes do edifício, mas é notório que seguiam os modelos e estilos lusos, com as normas tridentinas consolidadas. No Porto, em 1585, se estabelecia que a igreja fosse:

[...] tão grande que caibam nela todos os fregueses, bem emadeirada, e telhada, guarnecida, chã: com luzes suficientes, e boas portas, e fechaduras, e que tenha capela proporcionada, campanário, e sino, e o adro distinto e demarcado, os altares serão firmes, bem feitos, de grandura conveniente, com taboleiro, e degraus e nos lugares úmidos serão forrados de madeira, terão retábulos pintados com corrediças diante, e sacrário bem feito, dourado, e pintados nas Igrejas onde comodamente o possa haver, e panos pretos com Passos da Paixão pintados para o tempo da Quaresma, e frontais, e, por cima dos altares, haverá sobrecéus, ou guardanapos com suas franjas, havera toalhas para o altar tamanhas que cubram todo o altar por cima e pelas ilhargas até junto do chão bem concertadas, e panos para limpar as mãos, e toalhas para dar a comunhão, que alcancem de uma parte até a outra da Capela [...]. (CONSTITUIÇÕES..., 1585, p. 90)

Essas Constituições do Porto foram feitas por iniciativa de Frei Marcos de Lisboa (1582-1591) e mantiveram algumas normas das Constituições de $1541 .{ }^{9}$ As Constituições pós-tridentinas iniciaram o movimento de reforma, traçado pelo Concílio "em que se alteraram e mudaram muitas coisas". (MARTINS, 2002, p. 300) Os ditames pós-tridentinos, segundo esse autor, estabeleceram normas rígidas e uniformes quanto à colocação do sacrário nos altares. Ele identificou influências de dois italianos que promoveram a prática tridentina, Gian Matteo Giberti, bispo de Verona, e Carlo Borromeo, arcebispo de Milão, ao indicarem "que o sacrário deveria fixar-se na estrutura do altar-mor das respectivas catedrais" (MARTINS, 2002, p. 301), ocupando o seu centro. O mesmo uso foi recomendado para as igrejas paroquiais. Essa disposição foi aprovada, igualmente, pelo papa Paulo IV, que seguiu esse modelo em Roma.

Martins (2002, p. 301) viu em Giberti a maior contribuição, que colocou a figura de "Jesus Cristo, Filho de Deus, nosso Salvador" como o centro de toda criação. Para "Ele, deveria convergir todo o fiel" (MARTINS, 2002, p. 302) que quisesse alcançar a salvação. Essa convergência não só contribuiu para a sua colocação no centro do altar, como determinou a colocação do Crucificado sobreposto ao sacrário. Esse receptáculo passou a ser reservado ao Santíssimo Sacramento, que, até então, ocupava espaço periférico.

9 As primeiras Constituições Sinodais, da Diocese do Porto, foram impressas em 1496. (MARTINS, 2002) 
Esse programa sobre o sacrário do Porto não está especificado minuciosamente nas Constituições baianas, mas, como se verá adiante, se fazia a mesma exigência em relação ao altar-mor e ao sacrário, mostrando que o processo de adoção dos procedimentos foi copiado das normas conciliares e se multiplicaram no mundo ibérico. Em comum, tanto as Constituições do Porto, quanto de Lisboa, de Braga e demais bispados e arcebispados recomendavam que, edificadas e prontas, as novas igrejas pediam, novamente, a licença eclesiástica para verificar se estavam bem feitas e se os altares eram convenientes e tinham os apetrechos necessários para dizer a missa.

Além dos altares-mor, as igrejas compor-se-iam de altares laterais, ao menos um púlpito e confessionários, pias de água benta, pia batismal, sinos e "casa de sacristia". De acordo com o Direito Eclesiástico e o Sagrado Concílio de Trento, proibia-se a celebração da missa fora das igrejas, capelas, oratórios e ermidas, não podendo ser realizada no campo, ou em outro lugar, nem em igreja interditada, violada ou "poluta", nem ermida, capela ou oratório particulares "não sendo aprovados e visitados pelos superiores do arcebispado, com exceção em caso de doença e de missionários". (CONSTITUIÇÕES..., 1719, p. 145, 1853, p. 164)

No entorno e circunferência das igrejas, se colocariam adros para receber fiéis e peregrinos, cujas dimensões seriam marcadas pelo provisor, ou vigário geral, e cemitérios capazes para "neles se enterrarem os defuntos", tudo constando em autos, nos quais se registravam as demarcações, que seriam depositados no Cartório Eclesiástico, além de ter traslado no Cartório de cada uma das igrejas. (CONSTITUIÇÕES..., 1719, 1853)

Terminadas e aprovadas as obras, se faria a sagração do templo, de acordo com o Pontifical Romano, principalmente das catedrais e igrejas paroquiais. Anotariam-se, também, todos os autos e escritura de sagração, guardados no respectivo Cartório e no da Sé, declarando o dia, mês e ano da sagração, registrando também esses dados em uma pedra, que era colocada na parede, junto à porta principal da igreja. (CONSTITUIÇÕES..., 1719, 1853)

Como já se salientou, o tamanho deveria ter espaço suficiente, capaz de abrigar os fregueses da paróquia e gente de fora, principalmente as igrejas que eram alvo de romarias. Isso explica a posição, em lugar elevado ou aberto, de grande parte das igrejas construídas ou remodeladas em Salvador no século XVIII, como a Igreja do Santíssimo Sacramento e Santana, a Igreja e Convento da Piedade ou a Igreja dos Aflitos. As igrejas peregrinas passaram a ter, para abrigar os fiéis e seguindo as recomendações, os alpendres laterais, como a Igreja do Bonfim, ${ }^{10}$ em Salvador, ou da Divina Pastora, na então vila do mesmo nome, em Sergipe. ${ }^{11}$

10 Corredores laterais abertos e fechados posteriormente.

11 Unido à capitania da Bahia até 1820. 
As Constituições determinaram o plano interno das igrejas - que consagraria a disposição espacial, ditada pelo Concílio - em forma de salão único, caracteristicamente barroco, cujo modelo já se praticava na metrópole e nos domínios lusos. A estrutura interna das igrejas seria em forma de cruzeiro, obrigatório nas igrejas paroquiais, com capela-mor, sendo esta colocada de tal forma que o sacerdote, no altar, ficasse de frente com o rosto para o Oriente, ou para o "meio dia, mas nunca para o Norte, nem para o Ocidente”. (CONSTITUIÇÕES..., 1719, p. 165) Para exemplificar a aplicabilidade dos ditames sinodais na Bahia, além de exemplares paroquiais e conventuais, pode-se citar o caso, relatado no "Santuário Mariano”, de 1707-1723, por Frei Agostinho de Santa Maria (1947, v. 9, p. 123), que deu notícias da ermida de Nossa Senhora da Guia, filial da matriz de Cotegipe, no lugar de Tamboatá, que dizia ser o santuário de fábrica "moderna à Romana, e tem a porta principal para o Nascente". ${ }^{12}$

Todas as igrejas passaram a formar um grande salão, às vezes com área da nave livre, como a Igreja do Bonfim, que possui altares laterais embutidos nas paredes, ou outras com altares laterais salientes, intercomunicantes ou não, como na Igreja de Santa Teresa, hoje no Museu de Arte Sacra de Salvador, ou a própria Igreja do Convento franciscano. Este último modelo deixa ver melhor o cruzeiro, ou os braços bem-marcados da cruz latina.

A recomendação era que se construísse a nave da igreja de forma a permitir que todos os fiéis tivessem uma visão ampla do altar-mor. Tendo o barroco recebido influências do teatro de ópera europeu, o altar-mor e o presbitério transformaram-se "num palco", onde as cenas da Santa Missa se davam, incluindo cortinas de veludo, ou outro tecido, a depender da moda, como as de boca de palco. Em muitos arcos de altares ainda eram encontrados arremates com sanefas, próprias para encobrir a parte superior das cortinas. Ao contrário das igrejas medievais e renascentistas europeias, o barroco adotou a forma simples de salão, de dimensões não monumentais.

Aconselhava-se, no caso do Brasil, no qual as freguesias eram muito extensas, que se edificassem capelas que recepcionassem alguns fregueses, que poderiam ali receber os Sacramentos, devido à dificuldade que havia em se deslocarem para recebê-los nas paróquias. Para poder receber os recém-nascidos e batizá-los, essa capela deveria ter pia batismal, mas cabia ao pároco da igreja paroquial administrar o Sacramento, não podendo ser outro ministro eclesiástico nem mesmo os missionários, sem licença do Arcebispado. (CONSTITUIÇÕES..., 1719)

12 Aliás, as notícias das imagens marianas da Bahia foram informadas pelo Arcebispo D. Sebastião Monteiro da Vide a Frei Agostinho de Santa Maria, daí a referência à obediência às normas das Constituições. (SANTA MARIA, 1947, v. 9, p. 181) 
É interessante ressaltar que a grande maioria dos edifícios religiosos em Salvador, na Bahia, ou mesmo em outros lugares do Brasil, não tem autoria identificada, quer em relação à construção do edifício, quer da sua decoração interna ou externa e do patrimônio móvel, como imagens, talhas, prataria, móveis em pedra ou madeira, entre outros. Perdida a maior parte da documentação dos edifícios sobreviventes, poucas obras tiveram seus autores identificados. Deve-se salientar que era do proceder da época não exaltar pessoa que não fosse o Rei, e manter-se o anonimato sobre artistas e artífices, visto que a cópia era a regra entre arquitetos, pintores, escultores e artífices - estes últimos então chamados "oficiais mecânicos". Pela sua organização de trabalho, eram obras coletivas (cuja execução podia durar muitos anos), feitas sob a maestria de indivíduos sucessivos, portanto, com a participação de várias mãos e cabeças, sendo difícil se determinar as autorias. (FLEXOR, 1998, 1999a, 1999b)

Aos leigos, e mesmo aos religiosos, era proibido se destacarem entre seus pares. Em função das Constituições, e sob pena de excomunhão maior e 50 cruzados de multa, nenhuma pessoa secular ou eclesiástica, de qualquer qualidade ou condição, podia colocar "escudos de armas", ou quaisquer "insígnias, ou letreiros nos portais, paredes, ou em outra parte de dentro, ou de fora das Igrejas", ou outros edifícios pios, sem especial licença do Arcebispado, dada por escrito. Sem essa licença, além das penas acima, seriam submetidos à censura dos visitadores, que mandariam "raspar, tirar, ou quebrar em termo breve" essas marcas. (CONSTITUIÇÕES..., 1719, p. 168)

Essa foi uma das razões pela qual Jaboatam (1858-1862), o cronista da igreja mais importante de Salvador, e que escreveu sua obra durante a construção e decoração da maior parte do conjunto franciscano baiano, só citou um entalhador, o irmão leigo Frei Luiz de Jesus, apelidado de "o Torneiro". Além dele, apenas um painel do presbitério identifica a oficina de Bartolomeu Antunes, de 1753, autora dos azulejos desse ambiente, mas como é sabido, era obra portuguesa de origem, como toda a azulejaria setecentista ainda existente nos edifícios religiosos brasileiros.

Muitas igrejas, em Salvador, e na Bahia e no Brasil no geral, foram construídas, reformadas ou reconstruídas para seguir as novas normas "à romana”. Nem todas, no entanto, puderam seguir a norma de ter sua porta principal voltada para o Oriente, devido à topografia, especialmente na capital baiana, ou porque apenas passaram por reformas de edifícios pré-existentes. As reformas e construções se deram a partir dos princípios do século XVIII, algumas quase que simultaneamente à aprovação das Constituições. A construção da Igreja da Ordem $3^{a}$ de São Francisco iniciou-se em 1703, e a segunda Igreja do Convento de São Francisco em 1708, por exemplo. 
Espaço importante, principalmente para os ofícios internos da igreja, era o coro. Nele, tanto na Sé, quanto nas igrejas dos conventos, se rezavam as Sete Horas Canônicas: Matinas, Laudes, Prima, Terça, Sexta, Nona, Vésperas e Completas, de acordo com os respectivos estatutos. Para a realização desses ofícios, os coros eram providos de móveis especiais e específicos, como a estante, na qual se apoiavam os antifonários, cadeirais e capela.

Por se tratar de construções eretas em sociedade ainda em fase de consolidação, as Constituições Primeiras do Arcebispado da Bahia determinavam como deviam ser os edifícios religiosos, sua ornamentação, interna e externa, bem como indicavam quais eram os objetos necessários para os ofícios religiosos, ofícios para defuntos e sua manutenção. Verificou-se que as Constituições do Algarve, de 1554, por exemplo, não traziam recomendações quanto à construção e decoração dos edifícios - presentes em várias outras Constituições lusas -, mas citavam, tão somente, os mesmos apetrechos de culto, especialmente os de prata.

$\mathrm{Na}$ Bahia, determinavam, ainda, os objetos de culto, a decoração e mesmo o tipo e posição do mobiliário, como bancos, cadeiras, grades, bancadas de altares, além dos confessionários e móveis de sacristia, entre outros. Homens e mulheres não podiam se misturar dentro da igreja. A disposição dos assentos separava os sexos, ficando todos com os rostos voltados para o altar-mor. Os "bancos para os homens se assentarem, se porão das partes travessas para baixo detrás das mulheres", onde a igreja permitisse. ${ }^{13}$ Todos os leigos, ou eclesiásticos, e mesmo os regulares estavam proibidos de se assentar em "cadeiras de espaldas", ${ }^{14}$ ou tamboretes dentro da capela-mor, exceto as mais altas dignidades eclesiásticas. ${ }^{15}$ Nem mesmo o pároco tinha esse privilégio. Poderia ficar no altar-mor, e apenas para celebrar a missa e "para fazer estação", ${ }^{16}$ quando não pudesse fazer do púlpito ou em pé no cruzeiro. (CONSTITUIÇÕES..., 1719, 1853) Os escravos ficavam no fundo das igrejas. Note-se, por exemplo, que os altares das únicas irmandades existentes no conjunto franciscano de Salvador - as de São Benedito e Santa Ifigência - estão no terceiro altar lateral, direito e esquerdo, junto às portas de acesso à portaria do Convento; quanto à Ordem Terceira de São Francisco, encontra-se no fundo da nave.

Entravam no rol das exceções, no uso das cadeiras de espaldas, que muitos chamaram mais recentemente de "cadeiras de estado", os cardiais, patriarcas, arcebispos, bispos, núncios apostólicos, duques, marqueses, condes, governado-

13 As Constituições do Porto, de 1585, um pouco mais de um século antes, determinavam as posições ao contrário, homens na frente e mulheres atrás. Muitas igrejas baianas só receberam bancos no século XIX.

14 Cadeiras de encostos altos.

15 Nos Algarves, fazia-se a mesma proibição, e mais, sob a ameaça de excomunhão. (CONSTITUIÇÕES..., 1554) A mesma proibição se encontraria, alguns anos depois, nas Constituições do Porto (1585).

16 Sermão. 
res, inquisidores e visitadores, portadores dos hábitos de qualquer das Ordens Militares, mas nunca na capela-mor, quando se rezava missa. Dos civis, apenas os componentes da Câmara, quando oficialmente reunidos - a de Salvador ou de outra vila -, poderiam ocupar cadeiras com encosto alto. Os únicos leigos que teriam acesso à capela-mor seriam os que fossem cantar, tanger algum instrumento ou ajudar nos ofícios divinos - especialmente se a igreja fosse pequena - ou nos dias de festas. (CONSTITUIÇÕES..., 1719, 1853)

As pessoas mais graduadas faziam seus escravos conduzirem os seus assentos a partir da Casa do Governo, da Câmara, de quartéis ou mesmo aqueles de uso doméstico. Os vereadores e o juiz do Senado da Câmara usavam desse privilégio por ocasião dos ofícios feitos em sequência às procissões "del Rey" (FLEXOR, 1974), que eram patrocinadas pela edilidade. Continuaram a fazer uso de cadeiras próprias, embora as Constituições proibissem que "nenhum homem, de qualquer qualidade que seja, tenha na Igreja assento particular apropriado para si, ou para as mulheres, mas os assentos sejam comuns e iguais para todos". (CONSTITUIÇÕES..., 1719, p. 281) Esse uso se deu, sobretudo, nas festas de Corpus Christi e nos primeiros anos do século XVIII. Era costume antigo, mantido por até 1828 .

A partir das Constituições, o sacrifício da missa passou a ter um valor extraordinário, por celebrar o próprio sacrifício de Cristo. Por ocasião da publicação dessas normas, algumas igrejas da cidade da Bahia e outras do Recôncavo não necessitavam de ornamentos, por estarem bem-providas, de acordo com pareceres de visitadores. Recomendava-se, então, que as outras tivessem alguns objetos, no mínimo, para a celebração do Santo Sacrifício da Missa e ofícios divinos, bem como para as procissões, extrema-unção e para a exposição do Santíssimo Sacramento. (CONSTITUIÇÕES..., 1853) Cuidavam do protocolo, pois a missa era uma das cerimônias que dava mais visibilidade à igreja "à romana".

Os sacramentos, principais instituições de Cristo, requeriam um cerimonial próprio e, para tanto, usavam objetos (CONSTITUIÇÕES..., 1719) que, por sua importância, se transformaram em verdadeiras peças de arte. Todas as igrejas curadas, paroquiais ou capelas, em que se administrassem sacramentos, precisavam ter, além dos objetos mínimos exigidos, "pias batismais de pedra", cobertas, capazes de se fazer batismo por imersão; ${ }^{17}$ bem cobertas, com tampa e ralo vedável. As pias, de preferência, deveriam estar situadas em capelas com grades à roda, fechadas à chave. A água benta utilizada num batizado, ou apresentação, como chamavam, não poderia servir para outro batismo. Pelo ralo deveriam ser

17 A mesma observação é encontrada nas Constituições do Bispado do Algarve, de 1554; na de Lisboa, de 1588; e em outras mais. 
esgotados, além da água, as "relíquias"18 e panos que serviam para limpar os Santos Óleos aplicados nas cerimônias religiosas. (CONSTITUIÇÕES..., 1719) ${ }^{19}$

Recomendava-se que não se usasse a água da pia batismal para outro fim, sob pena de graves castigos. Tanto nas Constituições bainenses, como se dizia no século XVIII, quanto nas algarvias e nas portuenses ${ }^{20}$ ou lisboetas, recomendava-se que a água usada para o batismo deveria ser natural, não podendo ser "elementar", destilada ou artificial. (CONSTITUIÇÕES..., 1585) Essa água, obrigatoriamente, era benta na própria pia batismal, seguindo o ritual romano com a cerimônia estabelecida. Para o batismo por imersão, o religioso tomava "a criança por debaixo dos braços com as costas viradas para si” e, tendo a intenção de batizar, dizia as palavras de praxe e mergulhava "a criança na água com a boca para baixo uma só vez, pelo perigo, que pode haver sendo três as imersões". (CONSTITUIÇÕES..., 1719) $)^{21}$

As Constituições baianas, pelo fato de serem feitas para uma terra pouco habitada, numa fase de consolidação da sociedade, e necessitando de afirmação da Igreja Católica romana, davam mais minuciosamente informações para guiarem os bispos, arcebispos, ministros diversos, párocos, curas e fiéis. São muito mais extensas que as portuguesas ou mesmo as de Goa, na Índia. ${ }^{22}$ Falavam, por exemplo, como agir em relação à administração do Sacramento do batismo dos "monstros, que não podiam ser batizados", ou como agir com siameses, crianças perto da morte, crianças que não chegavam a ser retiradas do útero das mães, instruções a serem dadas às parteiras e, detalhadamente, como deveria ser o batismo dos adultos, incluindo os escravos e enjeitados. (CONSTITUIÇÕES..., 1719)

18 Chamavam-se "relíquias" os óleos sagrados vencidos, partículas de hóstias ou panos que tiveram contato com um ou outro elemento bento ou sagrado.

19 Os Santos Óleos velhos poderiam também ser usados "nas alampadas do Santíssimo Sacramento" como combustível. As Constituições do Porto recomendavam que todos os utensílios, objetos e vestuário que não tivessem uso fossem queimados e jogados no ralo das pias batismais, ou fossem enterrados no recinto da igreja. O ouro e a prata eram reaproveitados (CONSTITUIÇÕES..., 1585), como ficou também recomendado nas Constituições baianas.

20 Recomendava-se, no Bispado do Porto, prevendo o batismo de adultos, infiéis e filhos de escravos: "E quando houver de batizar a criança, a tomara com suas mãos por baixo dos bracinhos, as costas viradas para si, de maneira que ao meter da pia na água, vá a boca para baixo, e com a intenção sobredita de a batizar, como manda a Santa Madre Igreja, a emergirá debaixo da água uma só vez, com tal tento, que não aconteça algum perigo e dizendo juntamente as ditas palavras Ego te baptizoe'cet' (CONSTITUIÇÕES..., 1585, p. 6v-7), com algumas exceções. Da mesma forma se procedia no Algarves e na Bahia um século depois.

21 As crianças deviam ser batizadas dentro dos oito dias depois de nascidas. O ato era registrado em livro próprio das respectivas paróquias (CONSTITUIÇÕES..., 1719, p. 31) e valia como "certidão de nascimento" até o aparecimento do registro civil.

22 Exemplos, as Constituições de Lisboa, de 1537, tinham 85 fls; a de Évora, de 1565, tinha 88 fls; a de Coimbra, de 1591, 220 p.; a do Porto, de 1585, tinha 188 fls., enquanto as da Bahia têm 618 p. 
As Constituições da Bahia, como se disse, e com base em Benci, cuidaram da vida espiritual dos escravos. As Constituições do Porto (1585, p. $7 \mathrm{v})$ já haviam dado atenção, em parte, à questão do batismo de escravos, quando diziam:

E por que os negros, brazis, e Indios comunicam mais com os Cristãos pelo comercio que com eles lá se tem; e muitos se batizam, e se fazem Cristãos lá em suas terras: e assim os negros quando novamente os trazem: e outros também poderão ser que venham das ditas terras sem serem batizados, ou que estarão em duvida se o foram, ou não, por não se lembrarem: mandamos que se faça muita deligencia para se averiguar a verdade: e não se podendo saber, em tal caso, sendo primeiro instruido na Fé se devem tornar a batizar em duvida por aspersão com a dita condição $[. .].]^{23}$ (CONSTITUIÇÕES..., 1585, p. 7v)

Os Santos Óleos, benzidos anualmente na Quinta-Feira Santa, usados nas cerimônias do batismo e em outros sacramentos, precisavam estar em vasos ou âmbulas que, "quando não possam ser de prata, sejam ao menos de estanho", nunca de vidro, separando os frascos destinados aos meninos, enfermos e catecúmenos, identificados por letras e guardados num armário especial, fechado. Os óleos do batismo se guardariam, em princípio, num armário fechado, junto à pia batismal. Se fossem guardados longe, apenas o pároco ou sacerdote poderia transportá-los, e nunca um leigo. Cada igreja mantinha duas caixas ${ }^{24}$ com três âmbulas cada uma, e uma terceira caixa com uma âmbula com o oleo infirmorum..$^{25}$ Além desse móvel de guardar, outros foram recomendados. (CONSTITUIÇÕES..., 1719)

Foi nessa ocasião que, nas sacristias, passou a ser obrigatório um "caixão com gavetas, ${ }^{26}$ armários e caixas", ${ }^{27}$ para se recolherem os ornamentos, paramentos, cálices, patenas e o mais necessário, tudo sempre muito limpo, decente ${ }^{28}$ e bem-fechado. Esses móveis, obrigatoriamente, precisariam ser feitos até três meses depois da publicação das Constituições, salientando-se que eram mais necessários neste Arcebispado, "pois pelo clima da terra todo o cuidado é pouco"

23 As Constituições de Lisboa (1588, p. 5) também se referiam ao rebatismo, quando houvesse dúvidas, dos escravos.

24 Uma caixa mantinha os Óleos velhos até que chegassem Óleos novos. (CONSTITUIÇÕES..., 1719)

25 Óleo da extrema-unção.

26 Denominado hoje de "arcaz” pelos historiadores da arte e museólogos.

27 Hoje, denominadas "arcas".

28 As Constituições dos Algarves faziam a mesma recomendação. Mandava-se: "e terão em as sacristias das igrejas arcas ou armários para se guardarem as ditas vestimentas, cálice, e todos os outros ornamentos com limpeza e bom tratamento". (CONSTITUIÇÕES..., 1554, p. LXIJ) 
(Figura 1). Seriam feitos às custas da própria "fábrica" ou com recursos de construção e conservação da igreja. (CONSTITUIÇÕES..., 1719, 1853) Muitas sacristias de igrejas em Salvador foram construídas apenas nesse período. A sacristia era também o lugar de preparação para a missa, ocasião em que o sacerdote, ou poucos presentes, guardavam silêncio. Na hora marcada, o sacerdote se dirigia para o presbitério e altar, percorrendo normalmente, a depender do templo, um espaço bastante significativo, que, no século XVIII, chamava-se "via sacra", diversa da que se conhece atualmente, com esse nome, constituída pela sequência de cenas da Paixão de Cristo. (CONSTITUIÇÕES..., 1719)

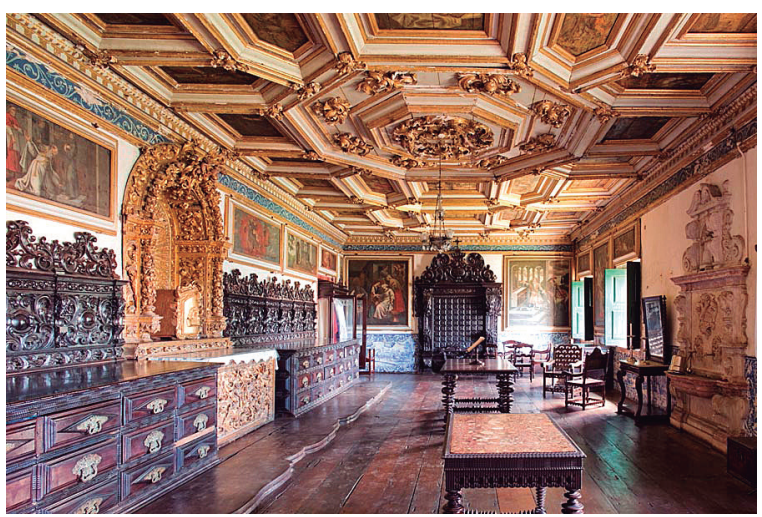

Figura 1 - Sacristia da Igreja do Convento de São Francisco Caixões, armários e lavatório - século XVIII

Fonte: Acervo pessoal.

O sacristão se incumbia das chaves dos "caixões e almarios", bem como da limpeza da sacristia e "da fonte do lavatório das mãos", com as toalhas necessárias. (CONSTITUIÇÕES..., 1719, 1853) Cuidava do culto divino e de servir bem às igrejas. Mandava-se que se escolhesse indivíduo com "limpeza de sangue, e é de boa vida, e costumes, e tem fidelidade, diligencia e cuidado para se lhe entregarem as coisas da Igreja", para guardar os vasos sagrados, a prata, ornamentos e mais móveis da igreja; acender e apagar as velas, tocar os sinos, limpar e ornar a igreja, ajudar nas missas, dar ao pároco o necessário para administrar os sacramentos, abrir e fechar as portas da igreja, levar a cruz nas procissões.

Guardião das chaves, o sacristão também cuidava da sacristia e todo o seu conteúdo, não podendo emprestar castiçais, peças de prata, armações, toalhas, panos de altares, vestidos das imagens de santos e mais ornamentos da igreja, para usos profanos, "nem ainda para figuras, que costuma ir nas procissões, batizados ou enterramentos". Sob pena de excomunhão e multa, proibia-se o em- 
préstimo dessas peças e o uso profano delas. Por outro lado, poderiam emprestar para outras igrejas, na mesma cidade, anexas ou filiais. (CONSTITUIÇÕES..., $1719)^{29}$

Tudo era entregue ao sacristão, depois do registro de um inventário, assinado por ele e pelo pároco. O inventário era lançado num livro que seria complementado com as peças que fossem compradas ou ofertas feitas depois da admissão do sacristão. Obrigados a se desfazer de alguma peça, por intervenção de visitadores, fazia-se, também, o registro no mesmo livro. Tudo era garantido por fiadores. (CONSTITUIÇÕES..., 1853) ${ }^{30}$

Em consonância com o Concílio Tridentinos e Bulas Apostólicas, mandava-se que todas as pessoas, "de qualquer estado, grau, ou condição que sejam", não usurpassem os "bens, censos, dízimos, frutos, ofertas, oblações ou quaisquer outros direitos, bens de raiz, adros, ou móveis de alguma Igreja secular ou regular, ou de outro algum lugar pio, ou rendas que pertençam a algum clerigo, ou comunidade eclesiástica em razão da Igreja, ou do beneficio". (CONSTITUIÇÕES..., 1719, p. 253, 1853, p. 241-242) Referia-se à própria igreja e adros, incluindo também pastos e fazendas. Nem a justiça secular poderia usurpar ou se imiscuir com esses bens.

Por outro lado, o Concílio e as Constituições permitiram, cada vez mais, a participação dos fiéis na construção, decoração das igrejas e na vida cristã, como a criação de instituições leigas, ou melhor, as Irmandades e, principalmente, as Ordens Terceiras. Eram associações mutualistas e filantrópicas que cuidavam tanto da saúde física e profissional dos irmãos, quanto da espiritual. $\mathrm{Na}$ falta de assistência de qualquer gênero, as irmandades eram espécies de associações às quais, invariavelmente, todos os habitantes pertenciam, às vezes a mais de uma. Tinham assistência material e profissional, no caso dos necessitados, pobres, viúvas, órfãos, doentes, entre outras formas de ajuda. Também a alma ficava assegurada de ter um lugar no céu após sua morte. A assistência também era dada na hora da morte, no enterro e, após a morte; sua alma recebia missas, procissões e orações. Tinham direito ao hábito da irmandade para serem sepultados, bem como acompanhamento e sepultura, especialmente por parte daquelas associações que abrigavam irmãos com melhores condições econômicas. Tinham direito até às carpideiras, se deixassem isso disposto em testamento.

29 Essa determinação é encontrada nessas Constituições de 1554. Também não podiam vender ou penhorar, tomar para uso próprio.

30 Mesmo as ermidas deveriam ter um guardião, o ermitão, que deveria ter as mesmas qualidades do sacristão. (CONSTITUIÇÕES..., 1853, p. 232) Já desde 1554, de quando datam as Constituições dos Algarves, se fazia essa recomendação, apenas em lugar do sacristão se entregaria ao tesoureiro; da mesma forma, apresentando fiadores. 
Existiam irmandades profissionais por cor da pele, por condição social e econômica, entre outras. As pessoas mais graduadas da sociedade normalmente pertenciam às ordens terceiras, embora estas últimas devessem estar ligadas às ordens primeiras, como a Ordem Terceira do Carmo ou a Ordem Terceira de São Francisco. Algumas foram criadas sem cumprir essa associação. Instituiu-se, por exemplo, a Ordem Terceira de São Domingos, sem que houvesse, na Bahia, a Ordem Primeira correspondente. A Ordem Terceira de Nossa Senhora da Conceição do Boqueirão, por sua vez, não tinha a quem se associar, por não existir ordem regular dessa invocação. Muitas se tornaram proprietárias de terras urbanas e rurais por força das doações feitas através de testamentos (CONSTITUIÇÕES..., 1853), quase sempre em troca de missas, em intenção de suas almas, das de sua família e mesmo pelas dos escravos. Esses gastos saíam da terça parte dos bens do inventário do doador, cumprindo cláusulas do testamento. ${ }^{31} \mathrm{O}$ testador podia usar livremente essa parte da partilha. Muitas doações feitas para as fábricas das igrejas provinham dessas fontes.

Todas as igrejas poderiam ter irmandades, que, junto com as capelas e hospitais, deveriam ter seus compromissos ou estatutos aprovados pelo Arcebispado e, muitos deles, pelo Rei. Eram exigidos os estatutos aprovados para evitar exageros, abusos, "juramentos indevidos", ou pensões onerosas ou mesmo indecentes, feitos pelos irmãos, "de que Deus Nosso Senhor, e os Santos não são servidos". As confrarias ou irmandades não podiam ser eretas sem autorização do Arcebispado, principalmente por serem compostas por leigos. Recomendava-se que, além de dedicarem as confrarias aos santos, não esquecessem de instituir, principalmente, uma ao Santíssimo Sacramento, ao nome de Jesus, Nossa Senhora e das almas do Purgatório, quando fosse possível. Os visitadores deveriam, sobretudo, de acordo com os Sagrados Cânones e do Concílio Tridentino, fazer cumprir as disposições pias, especialmente as instituídas em última vontade, pois estas fugiam à justiça comum, mas estavam diretamente subjulgadas ao Direito eclesiástico. (CONSTITUIÇÕES..., 1719)

Todas as igrejas licenciadas, em princípio, deveriam receber, para construção, reedificação ou ornamentação, ${ }^{32}$ um dote ${ }^{33}$ de 6 mil réis para cada uma, ${ }^{34}$ dado pelo Rei, posto que elas pertenciam à Ordem e Cavalaria de Cristo, da qual Sua Majestade era o "perpétuo administrador. ${ }^{35}$ Esse dote, evidentemente, não

31 O doador tanto podia destinar todos os bens para as igrejas quanto deixar para filhos naturais, ou, ainda, reservar para que um dos filhos fosse estudar em Coimbra, entre muitas outras alternativas. Diferente da atualidade, o total líquido dos bens, depois de pagas as dívidas, era dividido em três partes, uma delas ficava para o consorte sobrevivente, outra para aos filhos e a terceira custeava não só as missas, mas toda a cerimônia do enterro e sepultamento.

32 Concílio Tridentino, cap. 7, sessão XII. (REYCEND, 1786)

33 Para as igrejas das vilas, estava previsto um dote de 8 mil réis. (CONSTITUIÇÕES..., 1853)

34 Suspenso no Império.

35 Por força do Padroado. (CONSTITUIÇÕES..., 1853, p. 253) 
era suficiente para a construção dos edifícios, embora se afirmasse que "com muito liberal mão como tão zeloso, o Católico Rei manda dar grossas esmolas, assim para a edificação, como para a reedificação das ditas Igrejas". Todas as igrejas paroquiais pertenciam à mesma Ordem e Cavalaria. Em função disso, o Rei mandava pagar na folha de dotes das igrejas. (CONSTITUIÇÕES..., 1719) ${ }^{36}$

A maior parte dos gastos da fábrica das igrejas, no entanto, era reservada para a comunidade pagar. Nas próprias Constituições se deu notícia que, por ocasião da sua elaboração, foi constatado que, em algumas igrejas, a fábrica ficava limitada: "temos achado, que o que faltou por cobrar importa mui consideravel quantia, do que resulta estarem as Igrejas, sem o ornato devido, como vimos na visita que fizemos de todo nosso Arcebispado”. (CONSTITUIÇÕES..., 1719, p. 277)

Em geral, o dote régio era empregado na construção da capela-mor. As obras do resto do edifício se deixavam aos cuidados da população. Eram especialmente as irmandades, confraternidades e ordens terceiras que assumiam essas obras, além de se contar com o uso dos pequenos pagamentos de sacramentos, esmolas e doações pontuais ou castigos materiais por crimes de maior ou menor importância, como alguns furtos. O não pagamento dos dízimos, por exemplo, era considerado "pecado mortal", ${ }^{37}$ e cabia às altas autoridades eclesiásticas a sua absolvição, mas podiam, por outro lado, ser perdoados pelos párocos se o dízimo fosse pago ou doado aos pobres, ou se o produto do roubo ou do próprio dízimo não ultrapassasse 2 mil réis. O produto era, obrigatoriamente, destinado para a fábrica da paróquia à qual pertencia o penitente. (CONSTITUIÇÕES..., 1719)

Conforme a contribuição doada por pessoa de projeção, confrades ou irmãos de ordens terceiras, tinham o privilégio de serem sepultados em lugar especial no piso da igreja. Foi o caso de Garcia d'Ávila, que patrocinou a reforma dos altares colaterais da Igreja do Convento de São Francisco, em Salvador, na segunda metade do século XVIII, correspondentes à padroeira do Reino e conquistas lusas, Nossa Senhora da Conceição, e o de Santo Antônio, padroeiro da Província de São Francisco no Nordeste. Neste caso, o túmulo do patrocinador ocupava o lugar bem ao pé do altar da Conceição. Seus descendentes também tinham o mesmo privilégio, mas foram enterrados numa segunda linha, longe do altar. Foi a única sepultura que permaneceu no recinto da igreja. As demais foram transferidas para um memorial, no lugar da antiga horta do Convento. O enterramento no recinto das igrejas foi interditado nos meados do século XIX.

36 Para controlar essa doação, em função de Provisão Régia, de 8 de novembro de 1608, se escolhia um recebedor, entre os prelados ou cabido ou conego de muita confiança, para controlar seu emprego nas fábricas. (CONSTITUIÇÕES..., 1719)

37 Em muitos casos, por ser de costume antigo não pagar os dízimos à Igreja, as Constituições obrigavam o pagamento de conhecença. (CONSTITUIÇÃO..., 1719) 
De acordo com o Direito Canônico, era permitido a todo cristão ter uma sepultura no corpo da igreja paroquial, mosteiro ou adro, conforme escolhesse. O sepultamento no recinto das igrejas paroquiais, das irmandades ou ordens terceiras, ou num cemitério externo, era recomendado pelas Constituições. Ordenavam que os escravos, sendo batizados, fossem enterrados em lugar sagrado e não no campo ou no mato. Os fiéis tinham, por ser costume pio, antigo e recomendado pela Igreja Católica, o direito de serem enterrados em sepulturas em lugares sagrados e na sepultura que escolhessem na sua paróquia, ou outra, depois de ter obtido licença.

Recomendava-se que não fossem sepultados em lugares não sagrados, mesmo que o solicitassem, porque se classificava "esta sua disposição como torpe, e menos religiosa se não deve cumprir". (CONSTITUIÇÕES..., 1719, p. 315-316) As sepulturas se localizavam no corpo da igreja, especialmente na nave e capelas laterais, nos adros ou em cemitério, no seu entorno. Eram padronizadas, não sendo permitido se colocar pedra saliente sobre o túmulo, ou madeira, mas somente uma campa de pedra no mesmo nível do pavimento da nave. Tendo letreiro, ou armas, deveriam ser abertas, ou cinzeladas, na própria campa, não podendo ficar mais altas que ela. Nelas, era proibido "abrir cruzes, nem imagens de anjos ou santos, nem o nome de Jesus, ou da Virgem Nossa Senhora, pela reverência que se lhes deve, para que não suceda fazer-se-lhes desacato pondo-se-lhe os pés por cima". (CONSTITUIÇÕES..., 1719, p. 319) Caso transgredissem essa disposição, os infratores eram obrigados a reformar a sepultura. Eram os herdeiros ou testamenteiros que dariam essas providências. Nos Algarves, se fazia a mesma proibição, e mais, sob a ameaça de excomunhão.

Negava-se sepultura eclesiástica aos judeus ${ }^{38}$ hereges, cismáticos, apóstatas, blasfemos da Santa Fé, julgados pela igreja, blasfemos manifestos a Deus, Santíssima Trindade e Santos, assassinos ou suicidas, os que desafiassem a igreja publicamente, usurários manifestos, ladrões ou violadores de igrejas e mortos sem confissão. Também não podiam ocupar espaço nas sepulturas das igrejas os publicamente excomungados, religiosos professos que, por ocasião de sua morte, tivessem bens próprios contra as regras de sua religião, os que não tivessem confessado e comungado no ano anterior à sua morte, aos pagãos ou crianças que não tivessem sido batizadas (CONSTITUIÇÕES..., 1719), isto é, os que não professassem ou seguissem a igreja ou o ritual romano.

38 É interessante notar que Martinho Lutero, ou Martin Luther, também se opunha aos judeus, ao mesmo tempo em que se deve indicar que em nenhuma das Constituições consultadas há uma única referência à expressão “cristão novo". No entanto, certamente a expressão era utilizada, pois Bluteau (1722, v. 2, p. 303) logo depois acrescentou os verbetes "cristão novo" e "cristão velho", e, ainda, "cristanovice" e "cristãvelhice" no seu "Vocabulário". 
$\mathrm{Na}$ Sé e igrejas paroquiais, os religiosos eram obrigados a fazer, de acordo com o costume geral, e aprovado pela Arquidiocese, as procissões para os defuntos, nas segundas-feiras, com cruz, água-benta e com os reponsos e orações ordenadas. Passavam pelo adro, se nele houvesse sepulturas. Se as segundas-feiras coincidissem com alguma comemoração religiosa, a procissão seria feita nas terças-feiras. Nas freguesias do Arcebispado, onde não havia possibilidade do concurso de boa parte da população, essa procissão poderia ser feita nos domingos, exceto nos domingos de Páscoa, da Ressurreição, Pentecostes, Trindade ou festas de "primeira classe", ou festejos solenes na igreja. Os curas eram obrigados a "encomendar" as almas de seus fregueses cristãos, sob graves penas. (CONSTITUIÇÕES..., 1719)

As doações eram previstas por norma específica. Para "ornato e fabrica" das igrejas, eram permitidas as primícias, estas destinadas aos párocos, "oblações e ofertas de particulares". "As oblações e ofertas são tudo aquilo que os fiéis cristãos oferecem a Deus nosso Senhor, e a seus Santos nas Igrejas para ornato, e fabrica delas, ou para sustentação de seus ministros" [...]. (CONSTITUIÇÕES..., 1719, p. 180-181, 1853, p. 170-172) Como eram voluntárias, graças à devoção dos fiéis, incentivava-se o uso "desta louvável devoção". As paróquias tinham direito a essas ofertas, bem como as capelas ou oratórios, contanto que administrassem os Sacramentos. As oblações pertenciam aos párocos, que podiam repassá-las a algumas confrarias quando assim fosse determinado, e eram recolhidas por seus mordomos, confrades ou oficiais. Caso as igrejas não tivessem rendimento, os párocos eram obrigados a usá-las nas suas fábricas de acordo com a necessidade.

Feitas por voto, contrato ou deixadas em testamento de última vontade, essas doações eram passíveis de serem cobradas judicialmente, no fórum eclesiástico. Tanto serviam para melhorar o edifício, quanto para custear os ofícios e o pároco. Este tinha a possibilidade de usar essas doações, se fossem em espécies e se a igreja, capela ou oratório possuísse renda própria. Estava interditado de usar as ofertas feitas em ornamentos, vestidos ou "peças semelhantes", sob pena de excomunhão, ficando as mesmas a serviço da religião, não se destinando ao uso profano.

Porém oferecendo-se pés, braços, olhos de ouro ou de prata, ou de cera, mortalhas, círios, e outras coisas do gênero, em memória dos milagres, que Deus fez por intercessão dos Santos, as tais ofertas pertencem aos Párocos, e as podem aplicar a si, ou distribuir em usos pios, que os que os oferecerem declararam. (CONSTITUIÇÕES..., 1719, p. 182,1853, p. $171-173)^{39}$

39 As Constituições de Braga, de 1713, proibiam a colocação de ex-votos na igreja sem ser aprovada antecipadamente. (ROCHA, 1996, p. 187-202) Normalmente, tinham lugar especial, chamado hoje "Sala de Milagres", permitindo acesso aos fiéis. 
Não podiam, no entanto, tirar das igrejas todas estas últimas ofertas - ou ex-votos, como são chamadas hoje -, deixando "algumas para memória dos milagres e afervorar a devoção dos fiéis". (CONSTITUIÇÕES..., 1719, p. 182)

Aqui, é preciso lembrar que muitas dessas oblações eram em prata. Exemplares desses ex-votos são encontrados nos principais acervos de igrejas peregrinas, ou mesmo naquelas que a população elegeu como lugar de depósito de peças, em pagamento pelas graças alcançadas. Citem-se as peças do atual museu do Bonfim, em Salvador, ou a capela da Ordem Terceira do Carmo de Cachoeira. Outros ex-votos ficavam irremediavelmente aderidos aos templos, como aqueles de azulejos presentes na Igreja da Boa Viagem, em que os navegantes deixaram figurados os milagres alcançados em alto-mar.

A Igreja de São Francisco só tinha - depois de doar o terreno ao lado para a Irmandade da Ordem Terceira de São Francisco, para a construção de sua própria capela ${ }^{40}$ - duas irmandades, próprias dos escravos da comunidade, bem "como os de fora" dela, como diziam. Eram as irmandades de São Benedito e a de Santa Ifigênia, como já se fez referência. Eram, normalmente, irmandades pobres e contribuíram apenas para o ornamento dos altares de seus santos de devoção. Para a construção do edifício e decoração interna e externa, os franciscanos contaram com doações de uma confraternidade leiga, inicialmente restrita, composta de pessoas de posse, que, aos poucos, passou a admitir muitas pessoas, mesmo contra o protesto dos franciscanos. Assim, toda a construção do edifício da igreja, exceto a capela-mor original e sua decoração em ouro, deve-se a esses Confrades do século XVIII (FLEXOR; FRAGOSO, 2009), deslocando a discussão sobre a contradição entre riqueza do edifício e voto de pobreza dos religiosos franciscanos.

Os componentes das confraternidades, irmandades ou ordens terceiras tinham direito a ter uma sepultura dentro da igreja ou no cemitério externo, e os enterramentos eram regulados, da mesma forma, pelas Constituições. ${ }^{41}$ Os túmulos obedeciam a uma hierarquia ordenada pela igreja, mas, de qualquer forma, transformavam o piso, em toda sua extensão, em obra móvel, formando um quadrilátero dividido por pedra e tampos de madeira. Nos meados do século XIX, ${ }^{42}$ os pisos das igrejas passaram a ser substituídos por mármore ou pedras diversas, modificando o aspecto das naves.

Para fundação e construção de mosteiros e igrejas de religiosos regulares, masculinos ou femininos, precedia-se, como se disse, de licença (CONSTITUI-

\footnotetext{
40 Até essa doação, a Ordem Terceira de São Francisco ocupava uma das capelas da antiga Igreja de São Francisco.

41 Nos Algarves, segundo suas Constituições, também se regulamentavam os enterramentos. (CONSTITUIÇÕES..., 1554)

42 Com a proibição de enterramentos no corpo das igrejas e aparecimento dos cemitérios leigos.
} 
ÇÕES..., 1719, 1853), ${ }^{43}$ procedendo-se à vistoria do sítio, informações sobre a existência de rendas e bens para a fundação. Obrigava-se a construção em pedra e cal, não podendo ser de madeira ou de barro e com a condição de ouvir o parecer de outros mosteiros e conventos sobre a conveniência e inconveniência da nova fundação, já que os regulares não tinham bens próprios e dependiam, em boa parte, das esmolas que provinham da população. Aprovada pela comunidade, a licença era, então, dada pelo Arcebispado, que determinava o número de religiosos a serem admitidos, normalmente sugeridos pelo Rei. De tudo se faziam os autos e escritura, guardados no Cartório do Arcebispado, porque assim estava determinado pelo Concílio de Trento e motus próprios dos Papas Clemente VIII e Urbano VIII sobre a matéria. (CONSTITUIÇÕES..., 1719, 1853) ${ }^{44}$ Já era uma prática antiga, que permaneceu em uso. No testemunho do Arcebispo, D. Frei Manoel da Ressurreição, de 1689, constava que o Convento do Desterro se

Fundou com esmolas que lhe deram as pessoas que nele pretendiam recolher suas filhas e parentas, e com dinheiro de concertos legítimos entre os pais das religiosas, e o Mosteiro, e se sustentam com a renda que tem resultado dos juros dos dotes das mesmas religiosas, com o que é livre do padroado o dito Convento. (ALVES, 1950, p. 6)

Parte importante dos mosteiros de freiras era a clausura, tanto que o Concílio de Trento indicava, especialmente aos bispos e arcebispos, ameaçando-os à condenação pelo "Divino juízo" e à maldição eterna de Deus se não tivessem especial cuidado com essa instalação. (CONSTITUIÇÕES..., 1719)

Os particulares podiam criar capelas "de novo", isto é, novas, porém tinham que seguir os mesmos trâmites. As edificações religiosas com patrocínios particulares estariam sempre limpas, e a chave deveria estar na mão de pessoa devota, que se encarregaria de sua limpeza, de abri-la e fechá-la a qualquer tempo, marcando mais uma participação do leigo na administração religiosa. Zelavam, assim, pela aparência dos templos e dos seus ornamentos. Isso mostra que, além das modificações, provocadas pelas modas devocionais e estilísticas, havia as mudanças promovidas pelas irmandades, fiéis ou religiosos nas igrejas dos setecentos e oitocentos em Salvador. Isso explica também o desaparecimento de peças mais

43 “O Concilio Tridentino", sessão XXV, cap. 3. (REYCEND, 1786) O mesmo se observava nas Constituições Synodaes do Porto (1585, p. 87), exigindo veementemente a licença, sob pena de demolir o que fosse feito em contrário.

44 Mudada no Império. A licença passou a depender de Breve Pontifício e posterior licença e beneplácito do Imperador, bem como da autorização do Poder Legislativo para decretar o número de religiosos, rendas etc. (REGIMENTO..., 1853, p. 159)

45 O Convento das Clarissas não recebia, conforme esse documento, o dote do Rei, porque a comunidade e os pais das candidatas ao claustro se comprometeram a manter a instituição. 
antigas. $\mathrm{Na}$ medida em que se estragavam, eram "restauradas" ou substituídas por novas; ou, ainda, no caso da prataria, o metal era fundido e dava origem à outra peça. Precisavam estar sempre "decentes", como diziam, para manter o respeito, a fé e a piedade dos fiéis e afastar as superstições ou atitudes não condizentes com a purificação do culto.

Os visitadores e mais ministros eclesiásticos eram encarregados de zelar pela decência das sagradas imagens e verificar se naquelas "assim pintadas, como de vulto, há algumas indecencias, erros, e abusos contra a verdade dos mistérios Divinos, ou nos vestidos, e composição exterior". (CONSTITUIÇÕES..., 1719, 1853) Estas, se existissem, junto com as envelhecidas, eram retiradas, mandando-as enterrar nas igrejas, em lugares apartados das sepulturas dos defuntos. Recomendava-se, ainda, que os "retábulos das [imagens] pintadas, seriam tiradas do lugar, sendo primeiro desfeitos em pedaços" (CONSTITUIÇÕES..., 1719, 1853, p. 257-258), queimar-se-iam em lugar secreto, e as cinzas se jogariam, com água, na pia batismal, ou se enterrariam, como as imagens. E o mesmo se observaria com as cruzes de pau danificadas.

As Constituições do Porto (1585), com outras palavras, diziam a mesma coisa. ${ }^{46}$ Não se podia fazer pintar imagens por artistas não conhecidos e não aprovados pelo Bispado ou Provisor. Isso se devia ao fato de, em muitas igrejas do mesmo Bispado, existirem imagens e pinturas de santos "tão mal pintados, que não tão somente [sic], não provocam a devoção a quem as vê, mas antes dão materia de rir", e alegavam ainda "outros que não estão pintados conforme a verdade da escritura, e história que representam". Determinavam que nenhum pintor poderia executar pintura em retábulo ou qualquer outro suporte sem ter licença, antes se deveria "preceder verdadeira informação de como é bom oficial e que pinta as historias na verdade". Uma vistoria, feita em todas as igrejas, deveria determinar se as imagens e histórias que se encontravam expostas estavam em boas condições de serem aceitas, caso contrário, eram obrigados a substituí-las. A desobediência era castigada com excomunhão e 2 mil réis para as obras pias e para o meirinho do Bispado.

Com isso, o Concílio e, em especial, as Constituições tentavam afastar as crendices e superstições e não permitiam "[...] coisa alguma profana, ou inhonesta”, além de estabelecerem que não deveria existir - em nenhum retábulo ou altar, ou mesmo fora das igrejas, capelas ou ermidas do Arcebispado - imagens que não fossem reconhecidas pelas autoridades eclesiásticas e, reafirmando que fossem decentes, se "conformem com os mistérios, vida, e originaes que representam”. (CONSTITUIÇÕES..., 1853, p. 256) ${ }^{47}$

46 Vide a recomendação semelhante nas Constituições do Porto. (FERREIRA-ALVES, 1989, v 1, p. 45)

47 Disposto no Concílio Tridentino, sessão XXV. (REYCEND, 1786, p. 351) 
$O$ culto às imagens foi um dos pontos mais enfatizados pela Contrarreforma, porém, durante todo o período que se seguiu ao estabelecimento dessas Constituições até o século XIX, o número de invocações de santos foi muito limitado. A depuração das invocações dos Santos baseou-se no II Concílio de Nicéia (767), que já tinha eliminado uma série de nomes de santos séculos antes do Concílio de Trento. Evitava-se, com isso, a idolatria. Não só nas igrejas, mas também nos nichos e altares domésticos encontrava-se um número limitado de invocações de santos.

As próprias Constituições estabeleciam a preferência que as imagens tinham nos altares, devendo sempre preceder e estar no lugar mais alto a Santíssima Trindade, em especial a imagens do Cristo Nosso Senhor (Crucificado), conforme enfatizou Martins (2002). Em segundo lugar, viria a imagem da Virgem Nossa Senhora ${ }^{48}$, e em terceiro lugar, São Pedro, "Príncipe dos Apóstolos", como patrão e titular da igreja, que ocuparia o lugar principal nos altares em que não estivessem as duas primeiras. ${ }^{49} \mathrm{O}$ orago da igreja ocupava o lugar mais baixo no altar, sobre o tabernáculo ou nas colunas do arcocruzeiro, e teria o lugar mais alto, na ausência dos anteriores. (CONSTITUIÇÕES..., 1719) A imagem de São Francisco da igreja do convento do mesmo nome, em Salvador, esteve, até a grande reforma de 1926-1930, nas colunas do arcocruzeiro do altar-mor, tendo como seu par São Domingos. ${ }^{50}$ Tudo seria decente para que a população se recordasse dos benefícios e mercês recebidos, lembrasse dos seus milagres, dando graças a Deus, além de imitar suas vidas.

No século XVIII, todos os altares da capela-mor tinham um trono em sua composição. $\mathrm{O}$ alto desse trono era reservado à exposição do Santíssimo Sacramento. Sobre o sacrário, estava uma grande imagem de Cristo Crucificado (Figura 2). A capela-mor representava um "palco de teatro", 51 no qual a principal cena, a missa, se desenrolava e para onde todas as atenções deviam estar centradas. Até o século XIX, as cortinas se abriam para a missa ou exposição da custódia, guardando o Santíssimo Sacramento. Os degraus do trono sempre eram ornamentados com inúmeros castiçais e flores, naturais ou artificiais. Um Cristo Crucificado, hoje no fundo do templo, ocupou seu lugar principal no altar-mor

48 Principalmente a invocação de Nossa Senhora da Conceição.

49 Uma das principais paróquias de Salvador foi a de São Pedro Velho e, em 1709, o próprio D. Sebastião Monteiro da Vide deu licença à Irmandade de São Pedro dos Clérigos para erigir sua igreja. A atual importância secundária de São Pedro, em Salvador, deve-se, provavelmente, à falta de paradeiro do santo em seus templos que foram sendo destruídos, ou por ter sido, talvez, o protetor da Inquisição.

50 Essas imagens encontram-se, hoje, no corredor da via-sacra, na entrada da Sacristia. O conjunto que está no alto do trono do altar-mor é de autoria de Pedro Ferreira e foi ali colocado em 4 de outubro de 1930.

51 Deve-se lembrar que, durante a predominância do estilo barroco, houve a recuperação do teatro de ópera na Europa, o que influenciou nitidamente as representações dos mistérios ou estações da Paixão de Cristo. 
até a grande reforma pela qual passou esse espaço da Igreja do Convento de São Francisco da Bahia.

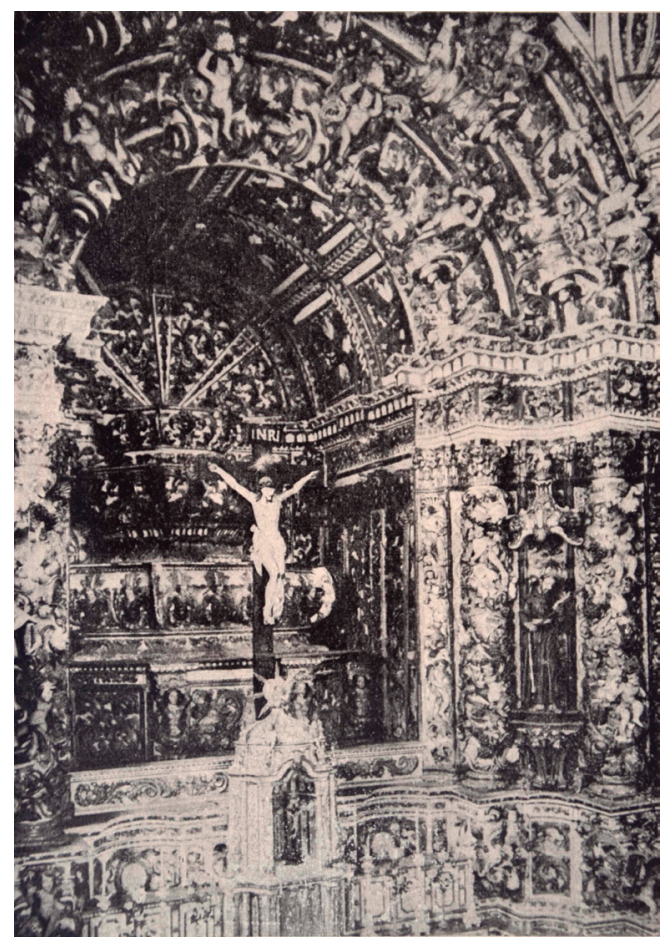

Figura 2 - Cristo Crucificado - século XVIII. Antigo altar-mor da Igreja de São Francisco, Reformado a partir de 1926

Fonte: Sinzig (1933).

Era absolutamente proibido colocar, nas igrejas paroquiais, dos regulares ou particulares, "Imagem alguma de Deus Nosso Senhor, da Virgem Nossa Senhora, dos Anjos, ou Santos pintados, ou de vulto" sem licença do Arcebispado, e determinava-se que fossem colocadas nas igrejas e altares as imagens de vulto bentas, na forma do Pontifical ou pelo Ritual Romano. Os funcionários eclesiásticos, como foi referido, não podiam permitir que fossem vendidas pinturas que, em lugar de exercitar a devoção, provocassem risos como "uns painéis, a que chamam ricos feitio e em que estão mal pintados alguns Santos". O meirinho do Arcebispado era encarregado de vistoriar os templos, sob pena de ser suspenso de seu ofício se encontrasse esses painéis com figuras malpintadas de santos e não desse providências. Era encarregado de apreender e levar a pintura ao vigário geral (CONSTITUIÇÕES, 1719, 1853) ${ }^{52}$ para as devidas providências.

52 Vide a mesma proibição nas Constituições do Porto. (FERREIRA-ALVES, 1989, p. 44) 


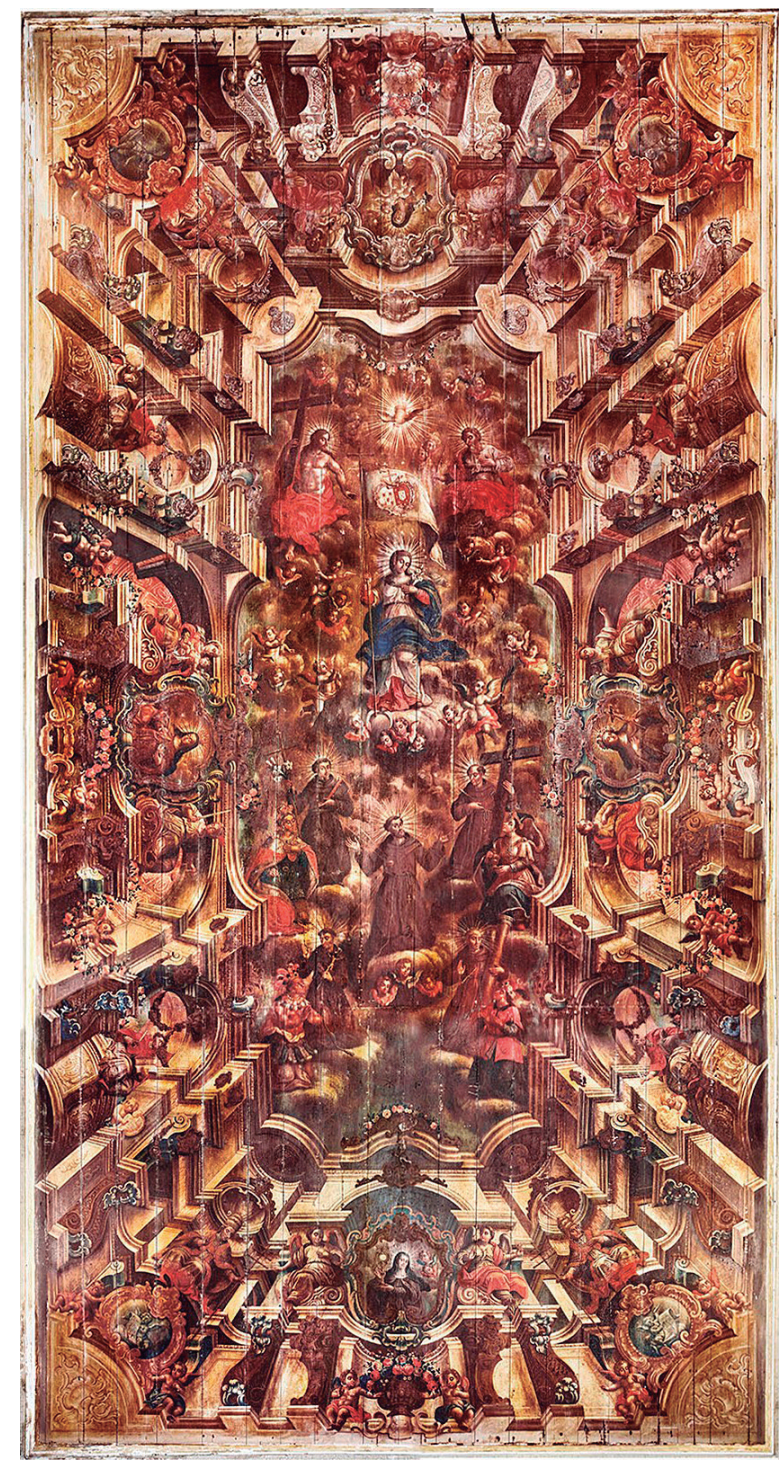

Figura 3 - Pintura barroca do teto da portaria do Convento de São Francisco/SSA - século XVIII

Fonte: Acervo pessoal.

Em função dessa determinação, foram reproduzidas tanto imagens quanto pinturas com modelos de Portugal, ou de outros lugares da Europa, aceitos pelo Arcebispado local. Normalmente, tinham inspiração em obras criadas, por exemplo, na Itália, aprovadas pela igreja reformada, reproduzidas de tratados ou estampas que circulavam no mundo católico romano. Alguns exemplos são as ilustrações do livro de Thomas Scheffler, com gravuras de Martin Engelbrecht, 
de Augsburg, 1732, a partir das originais de Augusto Casimiro Redelio (AMARAL JÚNIOR, 2010), que serviram de modelo e inspiração às pinturas emblemáticas da Casa do Capítulo, do Convento de São Francisco, de Salvador. As composições, usando os mesmos componentes do modelo, poderiam dispor os personagens de maneiras diferentes, mas a base principal continuava a mesma. Uma pintura de Michelangelo Caravaggio, A morte da Virgem, feita em 1601, para a Igreja de Santa Maria della Scala in Trastevere, de Roma, foi rejeitada por fugir completamente à iconografia aprovada pela Igreja Romana. ${ }^{53}$ Foi substituída pela pintura, de 1610, de Carlo Saraceni, que respondia mais às exigências da igreja reformada. ${ }^{54}$

A composição mais recorrente, na Bahia e no Brasil, está estampada no teto da portaria do Convento de São Francisco de Salvador, que mostra a Santíssima Trindade, a Virgem Maria, Santos Franciscanos, Bispos e Santas protetoras desses religiosos, representações dos então conhecidos quatro continentes (Figura 3). A composição barroca central é recorrente, encontrada tanto em tetos de igrejas como em dependências de conventos e em quadros pintados, a exemplo da Coroação de Maria, pintura do século XVIII, existente no Museu de Arte Sacra, da Universidade Federal da Bahia (UFBA). A forma e o espaço ocupados por Maria não fogem muito à composição de Saraceni. Da mesma forma aconteceu com as reproduções das imagens de vulto, com tamanhos diferentes, especialmente as de devoção da Virgem Maria ou Nossa Senhora da Conceição. ${ }^{55}$

Sendo Cristo consagrado como figura central da Igreja Romana reformada, as Constituições determinavam que a imagem da Cruz - desde Constantino, o símbolo dos cristãos - não podia ser pintada nem levantada em lugares indecentes, que se pudesse pisá-la, ou estar debaixo de janelas, nem sob paredes ou lugares sujos ou indecentes. Não eram proibidas as cruzes de pau ou pedra, ou mesmo pintadas, em lugares públicos, estradas, ruas, caminhos, mas sempre "quando for possível estarão levantadas do chão" (CONSTITUIÇÕES..., 1719, p. 270-271, 1853, p. 256-257), longe de lugares úmidos, o que explica sempre a cruz estar representada com o seu "calvário", ${ }^{56}$ isto é, sobre um pedestal significativo de algum relevo (Figura 25 e 26). Isso explica o porquê da imagem de Cristo Crucificado, agonizante ou expirante, que estava sempre presente em todos os oratórios domésticos e altares laterais das igrejas do século XVIII em diante (Figura 4). Os desobedientes concorriam à excomunhão maior ipso facto incurenda, além do pagamento de 2 mil réis para as obras pias.

53 Essa obra encontra-se, hoje, no Museu do Louvre, Paris. (WIKIPÉDIA, 2011)

54 A morte da Virgem, que continua a ocupar seu lugar na igreja citada em Roma. (WIKIPÉDIA, 2009)

55 A repetitividade do mesmo modelo levou um dos historiadores da arte mais conhecidos e citados da Bahia, Carlos Ott (1967, p. 74-75), a fazer referência à falta de habilidade dos pintores ou escultores que "plagiavam" outros artistas e até se "autoplagiavam".

56 Hoje chamado "peanha" ou "console". 


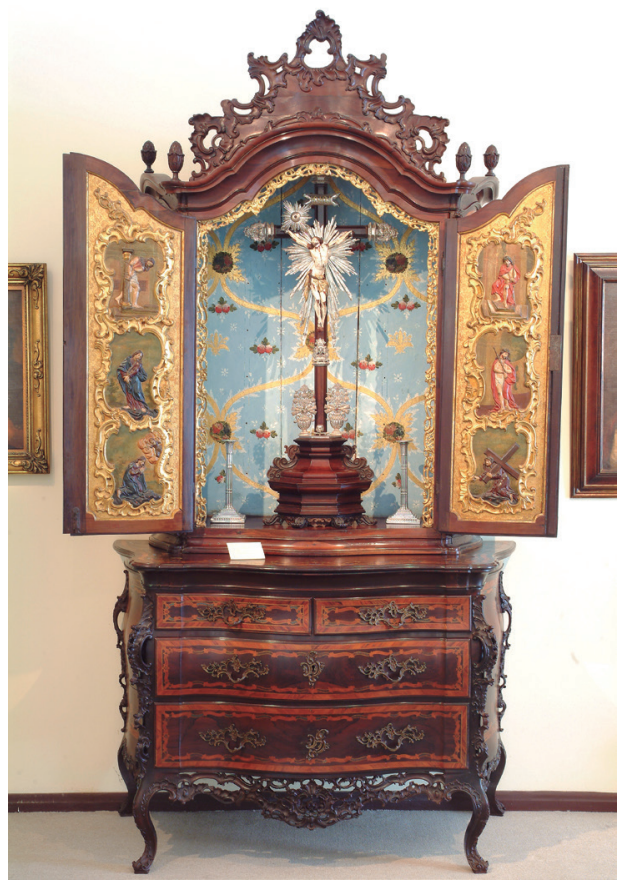

Figura 4 - Cômoda e oratório de dizer missa, Século XVIII, estilo rococó, com trabalho de marchetaria Fonte: Acervo pessoal.

A Cruz e o Santíssimo Sacramento tinham enorme valor simbólico. Segundo o apóstolo São Paulo, todo o católico deveria gloriar-se com a "sagrada árvore da Cruz", troféu e insígnia "gloriosa dos fiéis Cristãos, em que nosso Salvador Jesus Cristo nos remiu com seu precioso sangue, por cuja causa é bem que de todos seja tratada com toda a reverência". De igual forma, como a Cruz, os nomes de Jesus e da Virgem Maria não podiam ser escritos no chão ou lugar indecente. (CONSTITUIÇÕES..., 1719, 1853) Essa determinação, com a mesma ameaça de excomunhão, além de multa de 2 mil réis, é encontrada nas Constituições do Porto, de 1585, que mandava "que nenhuma pessoa possa por si, ou por outrem em modo algum pinte, esculpa, ou ponha Cruz no chão donde lhe possam por os pés, ou em outro algum lugar indecente, e desonesto". (CONSTITUIÇÕES..., 1585, p. 91v) E era o próprio Sagrado Concílio Tridentino que mandava que se "pintem retábulos, ou se ponham figuras dos misterios que obrou Cristo Nosso Senhor em sua Redenção, porquanto com elas se confirma o povo fiel em os trazer a memória muitas vezes, e se lembrem dos benefícios, e mercês, que de sua mão recebeu, e continamente recebe". (REYCEND, 1786, p. 345)

O uso das imagens de Cristo, em postura ou cenas de sua Paixão, de sua Mãe Santíssima, dos anjos e santos foi reafirmado pela Igreja Católica Romana, 
recomendando a construção de templos em sua homenagem, conforme a antiga tradição, e definições dos Sagrados Concílios, confirmando que "as ditas imagens, ou sejam de pintura, ou de escultura, se faça a mesma veneração, que aos originais, e significados, considerando que no culto, que a elas damos, veneramos, e reverenciamos a Deus Nosso Senhor, e aos santos, que elas representam". (CONSTITUIÇÕES..., 1719, p. 12) ${ }^{57}$ Assim, para poder se averiguar o programa traçado pelas Constituições baianas, com base sólida no Concílio que marcou a Contrarreforma Católica, transcreve-se todo o:

\section{Titulo XX - Das Santas Imagens}

Manda o Sagrado Concílio Tridentino, que nas Igrejas se ponham as Imagens de Cristo Senhor Nosso, de sua Sagrada Cruz, da Virgem Maria Nossa Senhora, e dos outros Santos, que estiverem canonizados, ou beatificados, e se pintem retábulos, ou se ponham figuras dos misterios que obrou Cristo nosso Senhor ${ }^{58}$ em nossa Redenção, por quanto com elas se confirma o povo fiel em os trazer à memória muitas vezes, e se lembrem dos benefícios, e mercês que de sua mão recebeu, e continuamente recebe; e se incita também, vendo as imagens dos Santos, e seus milagres, a dar graças a Deus Nosso Senhor, e a os imitar e encarregar muito aos bispos a particular diligencia, e cuidado que nisto devem ter, e também em procurar que não haja nesta matéria abusos, superstições, nem coisa alguma profana, ou 'inhonesta'. [...] Pelo que mandamos que nas igrejas, capelas e ermidas de nosso Arcebispado não haja em retábulos, altar, ou fora dele imagem que não seja das sobreditas, e que sejam decentes, e se conformem com os misterios, vida, e originais que representam. E mandamos que as imagens de vulto se façam daqui em diante de corpos inteiros pintados, e ornados de maneira que se escusem vestidos, por ser assim, mais conveniente, e decente. (CONSTITUIÇÕES..., 1719 , p. 268-269, 1753 , p. 256-257)

As Constituições consideravam que, quanto à quantidade dos ornamentos e móveis das igrejas, não se podia estabelecer "regra certa" ou única para todos, porque algumas paróquias tinham fregueses mais ricos e outras menos paroquianos e mais pobres, por isso estabeleciam que, pelo menos, tivessem todos os utensílios necessários para o culto de Deus e a celebração da missa e ofícios divinos. Faziam a ressalva que as paróquias "desta Cidade da Bahia, e algumas do

57 Cf. Concílio Tridentino, sessão XXIII, cap. 2, e sessão XXV. (REYCEND, 1786)

58 Leia-se Sete Estações da Via Sacra. 
Recôncavo não achamos que encomendar de novo, senão muito que louvar a piedade, e devoção com que estão ordenadas, e servidas". (CONSTITUIÇÕES..., 1719, p. 272)

Não se podia dizer missa "sem cálice de prata ao menos a copa, e a patena também de prata consagrados, nem com vestiduras sacerdotais, não sendo bentas e não serão rotas, nem índecentes, e quanto a possibilidade das Igrejas permitir, serão na cor conforme com o oficio de que se rezar". (CONSTITUIÇÕES..., 1719, p. 152-153) No altar, estaria a pedra d'Ara consagrada e em bom estado, e que pudesse abrigar a hóstia, cálice e corporais sagrados limpos, além de duas toalhas cobrindo o altar e missal em boas condições. O frontal do altar deveria combinar com a cor do hábito usado no sacrifício da missa. ${ }^{59}$ Antes de iniciar a missa, o pároco seguia o cerimonial romano, que indicava a forma de comportamento, deslocamentos, objetos - como cálice com os corporais - e maneira de cobrir ou descobrir a cabeça com barrete.

Para os altares e a celebração da missa das diversas paróquias do Arcebispado, além da pedra d'Ara, indicava-se ter cruzes, frontais, toalhas, cortinas, sacras, panos para as mãos, estantes ou almofadas, castiçais, alvas, amictos, cordões, manípulos, estolas, planetas, corporais com guarda e bolsas, cálices, patenas, palas, sanguinhos, panos ou véus dos mesmos cálices, missais, galhetas, caixas de hóstias e campainhas. Recomendava-se que todos os recipientes e ornamentos para a missa fossem benzidos, sempre de acordo com os Sagrados Cânones, em especial os cálices, patenas e os altares das igrejas, capelas e mesmo altares portáteis, tanto quanto os fixos, excetuando-se as toalhas de altares ou sinos. (CONSTITUIÇÕES..., 1719)

Cruzes com velas e mangas e capas pluviais eram usadas nas procissões. Para igrejas nas quais se expunham o Santíssimo Sacramento ou se fizessem outros ofícios, usava-se turibulo, naveta, pálio, custódia, âmbula para a comunhão e lanternas, sacrário e lâmpada, "que diante do Senhor esteja sempre acesa", além do livro de Ritual dos Sacramentos e catecismo. Tudo seria em quantidade e qualidade dentro das possibilidades de cada igreja. (CONSTITUIÇÕES..., 1719, 1853)

A partir da promulgação das Constituições, a Sé e as igrejas paroquiais, ou filiais do Arcebispado, foram obrigadas a fazer um inventário de peça por peça, desde a prata, os ornamentos e móveis, enfim, todos os bens móveis registrados individualmente, diante de testemunhas, num livro de tombo, descrevendo detalhes ornamentais dos móveis e peso da prataria, para que não fossem trocados. (CONSTITUIÇÕES..., 1719, 1853) Tanto o inventário da prataria, quanto o fim a ser dado ao vestuário ou peças de tecido e madeira velhos já estavam previstos nas Constituições do Porto (1585).

59 A limpeza dos objetos de culto também teve as mesmas recomendações em 1554 (CONSTITUIÇÕES..., 1554, p. XLIJ). 
Como os pertences das igrejas não podiam ser usados por leigos, recomendava-se que os ornamentos rotos ou velhos, que não se pudessem reformar e que não prestassem mais, fossem queimados e suas cinzas enterradas dentro das igrejas ou jogadas no "sumidouro" das pias batismais. O mesmo fim seria dado aos vestidos das imagens. Quanto às madeiras, pedras e telhas, não podendo ser utilizadas e sendo proibido o destino profano, recomendava-se que se desse para outras igrejas, mosteiros ou lugar religioso.$^{60}$ Se a madeira, por podre, não pudesse ser reaproveitada, também seria queimada e teria o mesmo destino dos ornamentos velhos. (CONSTITUIÇÕES..., 1719, 1853)

Todas as normas estavam minuciosamente descritas para que fossem seguidas, tudo com muita reverência e devoção, para afastar "as superstições, abusos, negociações, tratos profanos, práticas, discórdias" contra os ofícios Divinos, salientando as Constituições que os fiéis dessem exemplo: "neste nosso Arcebispado é isto necessário pelos muitos neófitos, pretos, e boçais, que cada dia se batizam, e convertem à nossa Santa Fé, e das exterioridades, que veem fazer, aos brancos aprendem mais, do que das palavras, e doutrina, que lhes ensinam porque a sua muita rudeza os não ajuda mais". (CONSTITUIÇÕES..., 1719 , p. 279,1853 , p. $264-265)$

Em atenção a esses neófitos, as Constituições estabeleciam o tipo de culto que se recomendava dar a Deus, à Virgem e aos Santos. A Deus, reconhecendo-o como Supremo Senhor, ao Filho e ao Espírito Santo se destinava o culto de "latria", ${ }^{61}$ que era a adoração devida somente a Deus, ao Cristo Redentor, "Unigenito Filho de Deus verdadeiro" e sua sacratíssima humanidade, e ao Santíssimo Sacramento da Eucaristia, porque "nele está realmente o mesmo Deus". Dispunha, ainda que, além disso, também o Lenho da Cruz, "as imagens do mesmo Cristo enquanto representam, e qualquer outra Cruz, como sinal que é representativo da verdadeira, em que o mesmo Senhor nos salvou" mereciam o mesmo tipo de adoração. ${ }^{62}$ Inclusive, a primeira disposição, colocada no Livro $1^{\circ}$, Título 1 , inciso 1 , das Constituições salientava que ninguém podia agradar a Deus se não acreditasse no mistério da Santíssima Trindade. O culto à Virgem Maria, "nossa senhora", se daria o culto de "hiperdulia", ${ }^{63}$ ou a veneração, por ser mãe de Cristo e possuidora de muitas virtudes, e "dulia" (CONSTITUIÇÕES...,

60 Ver Constituições. (1554, p. lxiv)

61 Latria compreendia a adoração, demonstrada através de prostração de joelhos em terra com a cabeça descoberta, as mãos juntas e levantadas, batendo no peito e fazendo outros atos exteriores de veneração.

62 O culto à imagem de Cristo e à cruz foi mudado no Império, pois, segundo alguns teólogos, este culto "só se dá a Deus, à Trindade Santíssima, a Christo Redentor nosso, ao Santíssimo Sacramento, porque nele está o Verdadeiro Deus realmente. Mas este culto não se dá ao Santo Lenho, etc, porque a este é dado o culto de Hiperdulia; e bem assim as imagens de Cristo”. (REGIMENTO..., 1853, p. 150)

63 Adoração feita com joelhos por terra e cabeça descoberta, fazendo uma oração. 
1719), ${ }^{64}$ que era outro tipo de culto, devido aos anjos e espíritos celestiais, bem como aos santos aprovados pela igreja como intercessores dos homens junto a Deus. A devoção à Virgem Maria foi severamente criticada por Martinho Lutero, ${ }^{65}$ por isso encontrou, na Contrarreforma, a reafirmação e reforço de seu culto.

No século XVIII, as invocações preferidas foram apontadas pelas imagens contidas nos oratórios particulares, cujas descrições podem ser encontradas nos testamentos e inventários baianos, por exemplo. Invariavelmente, continham um "Cristo com sua cruz e calvário", além das várias invocações da Virgem Maria, das Almas e Anjo da Guarda. Os santos preferidos, mais frequentes, eram Santo Antônio, São Domingos, São João Batista, São Francisco, São João Evangelista, São Pedro, São Pio V, Santa Teresa, São Felix, Santana, São José e São Gonçalo. (FLEXOR, 1997) Não era muito grande o número de invocações pela própria repressão feita pelas Constituições e pela Inquisição. Essas poucas invocações foram multiplicadas enormemente e, como a regra, era a cópia de modelos, elas se reproduziram em número considerável, com formas muito próximas umas das outras. Assim, depois do século XVI, mas especialmente no século XVIII, pode-se falar numa iconografia católica ocidental uniformizada.

Essa larga produção da imaginária de vulto tinha explicação no Concílio de Trento, que manteve todas as formas tradicionais de piedade e confirmou o culto a elas. (DELUMEAU, 1973) ${ }^{66}$ A Contrarreforma, o Concílio e as Constituições deram ênfase à proliferação de imagens como multiplicadoras da própria fé. Elas se faziam presentes, sob diversas formas, em todos os espaços religiosos ou espaço de manifestação pública e coletiva de religiosidade, como as procissões.

O Concílio havia estabelecido normas sobre as relíquias dos Santos ${ }^{67}$ e imagens sagradas para orientar tanto os artistas - que colaboravam para a visualização de todo o ideário religioso - quanto os que encomendavam as obras e os fiéis, que participavam na gênese de toda a obra de arte. As relíquias proliferaram por todos os templos, conventos e mesmo entre os leigos, chegando ao exagero. Os santos adquiriram, então, um valor extraordinário no imaginário popular, e era permitido, e recomendado, aos fiéis os tocar diretamente - transformando-os em verdadeiros amuletos -, embora as Constituições recomendassem, veementemente, que estariam tocando os próprios santos e que "não pensassem o contrário”. (CONSTITUIÇÕES..., 1719, p. 11, 1853, p. 9-10)

64 Reza, em pé ou de joelhos, com a cabeça descoberta.

65 Martin Luther.

66 Concílio Tridentino, sessão XXV. (REYCEND, 1786)

67 O vocábulo "relíquia" era usado no sentido de "resto", "sobra”, como nas Constituições (1719). Ao tratar do Sacramento da Extrema Unção, se referiam ao perdão das "relíquias dos pecados", que cabia aos párocos, ou confessores, absolver para o caso de morte. Também se referiam às “relíquias” de hóstia, pedacinhos que involuntariamente caíssem sobre a toalha, na hora da comunhão. (CONSTITUIÇÕES..., 1719) 
As relíquias eram parte do corpo ou outros objetos que, em vida, ou depois da morte, tivessem tocado o corpo do respectivo santo. Nenhum cristão poderia duvidar, segundo o Concílio de Trento, dos seus poderes. Era proibido comprar ou vender as relíquias, a não ser que fosse para resgatá-las dos hereges ou infiéis. Os exemplares comprados ou doados, necessariamente, vinham acompanhados por documentos que comprovassem sua legitimidade, e àquelas que não dispunham dessa comprovação, recomendava-se requerer a presença de visitadores, especialmente escolhidos para esse fim, no intuito de darem parte às autoridades eclesiásticas respectivas. Cometia o crime de simonia, se agisse de forma diferente.

Não se deve esquecer que as imagens dos santos foram combatidíssimas pela Reforma protestante, por isso mesmo a Contrarreforma católica teve nelas uma bandeira de luta, instando os fiéis a cultuá-las, a seguir seus exemplos e mesmo tocá-las. Os fiéis, antes de tudo, precisavam conhecer a intercessão dos Santos, suas invocações, veneração de relíquias e o legítimo uso das imagens, ${ }^{68}$ além, especialmente, das imagens dos santos e dos corpos dos mártires. (CONSTITUIÇÕES..., 1719) Se tomava parte do corpo, ou objeto de uso pessoal, sob forma de relíquia, colocada em "engastes, vasos, ou relicários, e guardadas tão decentes [...]". ${ }^{69}$ (CONSTITUIÇÕES..., 1719, p. 11) Quando fossem expostas, eram acompanhadas por velas acesas num altar, na presença de um sacerdote com sobrepeliz.

A do Agnus dei, guardada conforme as determinações do Papa Gregório XIII, necessariamente teria o repositório na cor natural "sem nenhum genero de ouro, pintura ou iluminação", sob pena de excomunhão maior. (CONSTITUIÇÕES..., 1719, p. 12) A grande maioria era engastada em bases ou medalhões com ornamentos em relevo, elaborados com cera de abelha. As freiras concepcionistas, antigas ocupantes do Convento da Lapa, que hoje residem num convento no bairro de Brotas, em Salvador, possuem uma interessante coleção desse tipo de relíquia. Havia um verdadeiro culto institucionalizado às santas relíquias, que se multiplicou em forma de bustos-relicários, nos altares, ${ }^{70}$ nas cruzes, medalhões, ou sob a forma de pingentes simples, de ouro ou prata, para uso pessoal, como acusam os inventários de número considerável de baianos, especialmente as mulheres.

68 Concílio Tridentino, sessão XXV. (REYCEND, 1786, p. 337-349).

69 Nem sempre eram “decentes", como a igreja recomendava, fossem sóbrios. D. Porcina d'Oliveira Mendes ofereceu um cordão de ouro ao Senhor dos Passos, da Igreja da Ajuda. O Arcebispo, D. Manoel Joaquim da Silveira, Conde de S. Salvador, ofertou um relicário de ouro cravejado de esmeraldas, com fragmento do Santo Lenho, pendente de colar em ouro. (CAMPOS, 1941)

70 É destacável o Cristo relicário do altar da capela interna do Convento de Santa Clara do Desterro, datado do século XVIII. 
As próprias Constituições acabaram consagrando a lenda de "Santa Úrsula e as Onze Mil Virgens", ${ }^{71}$ uma das poucas invocações as quais os jesuítas podiam fazer procissão pela cidade, no dia da Santíssima Trindade (CONSTITUIÇÕES..., 1719, 1853), e cujas relíquias encontram-se em dois bustos, no altar daquela Santa, na atual Catedral de Salvador. ${ }^{72}$ A angústia da salvação fez surgir, como uma de suas consequências, a divulgação, a defesa do catolicismo romano ao ponto de se morrer como mártir, o que fez surgir uma nova galeria de santos, como os Mártires do Japão ou do Marrocos, em função da multiplicação das relíquias.

As Constituições regularam tanto os atos religiosos em recintos fechados quanto em espaço público. Neste último caso, se enquadravam as procissões, verdadeiros teatros de ópera a céu aberto, nas ruas e praças da cidade. E se reputavam tão antigas que alguns autores as datavam do tempo dos apóstolos. Preconizava-se obedecer toda a decência e só permitir a presença de imagens de santos canonizados, obedecendo às proibições das Constituições, especialmente não a de não serem realizadas à noite - excepcionalmente a de Endoenças -, em que as mulheres não podiam participar. A noite era do domínio do Príncipe das trevas, o Demônio. (CONSTITUIÇÕES..., 1758)

As Constituições consideravam a "procissão como oração pública feita a Deus, por um comum ajuntamento de fiéis, [...] reconhecendo a 'Deus como Supremo Senhor de tudo"'. (CONSTITUIÇÕES..., 1853, p. 191) '73 As Ordens Terceiras, a Santa Casa e a Câmara tinham suas procissões. (FLEXOR, 1974) Excepcionalmente, os jesuítas tinham suas procissões licenciadas pelas Constituições, como se viu. Os irmãos da Ordem Terceira do Carmo ${ }^{74}$ faziam a da Paixão, reduzida ao Senhor morto, na Sexta-Feira Santa; a Ordem Terceira de São Francisco cuidava da procissão da Quarta-feira de Cinzas. A Ordem Terceira de São Domingos realizava a procissão do Triunfo da Cruz. A Irmandade da Santa

71 As Virgens foram multiplicadas por um erro de leitura das siglas XI MM VV = Onze Mártires Virgens, em que as consoantes dobradas indicavam plural. MM ou M, com til sobreposto, foi lido como mil em lugar de mártires. O próprio Arcebispo, D. Sebastião Monteiro da Vide, se referiu à Santa Ursula e às Onze Mil Virgens nas Constituições $(1719,1853)$.

72 Consta que as "sagradas cabeças das onze mil virgens", mandadas por Francisco de Borja através de, em 1575, chegaram à Bahia no dia de Corpus Christi, no mesmo ano. O bispo, D. Antônio Barreiros, no ano seguinte, as tomou por padroeiras. Segundo o certificado de 1719, elas se transformaram em Padroeiras do Brasil, por terem sido as primeiras relíquias de Santos que entraram na América portuguesa, fato confirmado em 158. (REVISTA DO INSTITUTO GEOGRÁFICO E HISTÓRICO DA BAHIA, 1948-1949, p. 199200) Certificado do Reitor do Colégio dos Jesuítas da Bahia sobre as relíquias existentes no santuário do mesmo colégio. Transcrição do documento existente na Biblioteca da Ajuda. Lisboa, pasta 52-X-2-no 76.

73 Equivalente à sessão XIII do Concílio de Trento. (REYCEND, 1786, p. 241)

74 As Constituições não especificam se a permissão era dada à ordem primeira do convento de religiosos regulares, ou à ordem terceira, irmandade de leigos. Antes das Constituições, as ordens terceiras ocupavam um altar dentro do edifício das ordens regulares, especialmente dos carmelitas e franciscanos. Só a partir das Constituições, estas iniciaram a construção de templos próprios. 
Casa se encarregava, na Quinta-feira Santa, da Procissão de Endoenças, que foi popularizada como Procissão dos Fogaréus, e no dia de Todos os Santos; a Irmandade dos Passos cuidava de Cristo, carregando a cruz na sexta-feira da Quaresma. Outras procissões podiam ser realizadas, como aquelas em homenagem aos oragos, mas com a licença do Arcebispado.

Como já foi dito, o Senado da Câmara patrocinava as procissões chamadas "del Rey". Entre elas estavam a de São Sebastião, Santo Antônio e São Francisco. Esta última era realizada no dia 10 de maio e se comemorava apenas em Salvador, por ele ser padroeiro dessa cidade. No calendário de festas fixas das Constituições, a festa desse santo estava entre as realizadas em dezembro. A mais importante de todas, no entanto, era feita pela Sé: a de Corpus Christi, à qual todos eram, sob convite, obrigados a concorrer. (CONSTITUIÇÕES..., 1719) Era custeada também pelo Senado da Câmara, como procissão real. Nessas procissões, as imagens e a religiosidade dos fiéis tinham maior visibilidade.

Algumas procissões tinham valor extraordinário, como aquelas dedicadas à Paixão de Cristo ou cerimônias correlatas. Os cultos da Paixão e da Virgem Dolorosa eram gerais, nas vésperas da Reforma, e foram recuperados pela Contrarreforma, sendo introduzidos no Brasil no movimento de expansão desta em terras descobertas. Nesse culto à Paixão de Cristo, toda a atenção estava voltada para as diversas passagens do sacrifício do Filho de Deus, chamados "Passos" ou "Mistérios da Paixão", e que eram, então, em número de sete. ${ }^{75}$ Com o crescimento e popularidade dos Passos, a tendência foi aumentar a teatralidade dos personagens barrocos, criando um grande impacto emocional nos acompanhantes ou na assistência.

Assim, a realidade espiritual efêmera tornava-se palpável, podendo ser experimentada na íntegra. E todos participavam, de uma forma ou de outra, do evento. Não havia espectador passivo. Participava, no mínimo, como testemunha histórica e, num outro nível, através do seu envolvimento emocional. Criadas e enfatizadas pela matriz sensorial das procissões, as imagens causavam emoções e lágrimas nos fiéis. As lágrimas, inclusive, eram recomendadas pelas Constituições. À sua passagem, as Constituições recomendavam que os fiéis se prostassem de "[...] joelhos em terra com a cabeça descoberta, e mãos juntas, e levantadas, batendo nos peitos, e fazendo outros atos exteriores de veneração, que correspondem ao culto interior de nossos corações, reconhecendo-o por Deus, e Supremo Senhor". (CONSTITUIÇÕES..., 1853, p. 8-9) (6 $^{76}$

Nessas procissões, eram utilizadas, sobretudo, as imagens de roca, que permitiam expressões e gestos teatrais, que possibilitavam a comunicação direta com

75 Senhor dos Passos, "Ecce Homo", o Senhor na Prisão, o Senhor da Coluna, o Senhor da Pedra, o Senhor no Horto, o Senhor Glorioso, como eram chamadas as diferentes representações em duas ou três dimensões.

76 Que transmitia a recomendação das sessões XIII e XXIII do Concílio Tridentino. 
os fiéis nas ruas, cumprindo as recomendações de Santo Inácio de Loyola, buscando atingir os fiéis pela visão e pelo coração mais do que pela razão. Também se montavam passos fixos em várias partes do percurso das procissões na cidade, compostos com as imagens de vestir. (FLEXOR, 2005) As Constituições referiam-se às "antigas [imagens] que se costumam vestir", o que significava que a sua utilização antecedia à aprovação dessas Constituições, em 1707. Isso mostra o hábito de vestir as imagens, para as quais se ordenava, então, que fossem

[...] de tal modo, que não se possa notar indecência nos rostos, vestidos ou toucados; o que com muito mais cuidado se guardará nas imagens da Virgem Nossa Senhora, porque assim como depois de Deus não tem igual em santidade, e honestidade, assim convém que sua imagem sobre todas seja, mais santamente vestida, e ornada. E não serão usadas as imagens das Igrejas, e levadas a casas particulares para nelas serem vestidas, nem serão com vestidos ou ornatos emprestados, que tornem a servir em usos profano. (CONSTITUIÇÕES..., 1719, p. 269, 1853, p. 256-257) 77 $^{77}$

Já se encontravam referências às imagens de vestir nas Constituições do Porto, de 1585, que ordenavam que não se vestisse ou ornasse as imagens com vestidos emprestados e recomendavam, igualmente, que eles não se transformassem em uso profano. Também não podiam ter a feição e cor que fossem indecentes, especialmente se devia ter o "maior cuidado [...] nas vestiduras, toucados, e cores das imagens da Santíssima Virgem Maria Nossa Senhora, porque assim como depois de Deus não tem igual em santidade, e honestidade, assim convém que sua imagem sobre todas seja mais santamente vestida, e ornada [...]”. (CONSTITUIÇÕES..., 1585, p. 89v) As recomendações, na realidade, são iguais àquelas das Constituições baianas, com mais de um século de distância no tempo, como se vê na citação acima.

Ao lado desse ciclo da Paixão, a festa de Corpus Christi, referida acima, era uma das mais importantes procissões "del Rey" e fazia o contraponto àquelas da Paixão, ópera triste. Esta era a ópera alegre. A festa do Corpo de Deus repetia, num denso simbolismo, o auto da transfiguração de Cristo no Sacramento da Eucaristia. Embora tivesse espírito diferente, ela fazia parte do mesmo ciclo da Paixão. Teve, porém, a data comemorativa mudada.

E posto que a Igreja Católica por ocupada neste dia Quinta-feira Santa - com as confissões dos fiéis, sagração dos Óleos, cerimônia do Lavapés, e mais ofícios Divinos, e

77 Referente ao Concílio Tridentino, sessão XXV. (REYCEND, 1786) “Tolhas de alento". "Alentos, ou toucados de algumas freiras são o que acompanha, e orna de uma, e outra banda a toalha da cabeça". (BLUTEAU, 1722, v. 7, p. 213) 
não poder então solenisar plenamente tão alto Sacramento, reservou a festa de sua instituição para a quinta-feira depois do oitavário de Pentecostes. (CONSTITUIÇÕES..., 1853, p. 51-53)

A procissão de Corpus Christi promovia o encontro da religiosidade com algumas representações pagãs, herdadas da mitologia clássica. ${ }^{78}$ Compunham a procissão as alegorias do dragão, da serpente, bem como estandartes dos santos protetores dos ofícios mecânicos, padeiras, confeiteiros etc., e a imagem de São Jorge, em tamanho natural, a cavalo e com pagens vivos, além de danças, música e flores no chão. (FLEXOR, 1974)

Não havia missa nessa data, por outro lado, se determinava que se fizesse exposição solene do Santíssimo Sacramento nas igrejas que tivessem sacrário. Ornava-se o "sepulcro" ou sacrário na Igreja da Sé (Figura 5), acendendo ao menos 40 velas de cera branca, do tamanho compatível com a duração da cerimônia de sua exposição, sempre usando o cerimonial romano, com a mesma solenidade, culto e ornato possível, e havendo vigília dos religiosos durante esse período. (CONSTITUIÇÕES..., 1719)

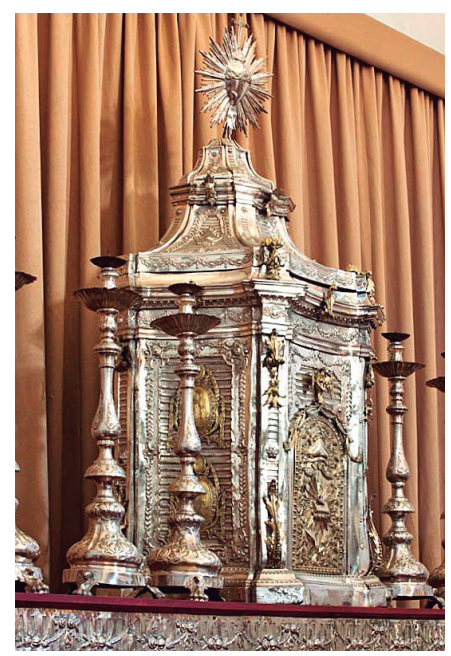

Figura 5 - Sacrário da antiga Sé de Salvador, Século XVIII Fonte: Acervo pessoal.

A luz de velas era o sinônimo de festa em templos, quase todos desprovidos de janelas, usando a penumbra para recolhimento e meditação. Como sustentáculo das velas, usavam-se castiçais ou veladores, de prata, ou, mais tarde, de

78 Segundo alguns autores, a festa data do século XIII e foi divulgada pelo papa Urbano VI, nesse mesmo século, em função do abalo sofrido pela fé dos homens, provocado pela decadência do feudalismo. 
madeira, expostas no trono do altar-mor, inicialmente destinado à exposição do Santíssimo Sacramento, e não ao orago da igreja. Houve ocasião em que o trono do Santíssimo da Igreja de São Francisco foi ornamentado com 60 castiçais, entalhados e prateados, com velas de cera acesas. (FLEXOR; FRAGOSO, 2009) Normalmente, não se podia fazer vigília nas igrejas, salvo nas noites de Natal e da Semana Santa, ocasião em que o recinto deveria ser muito iluminado e vigiado. (CONSTITUIÇÕES..., 1719)

Na Sexta-feira Santa, depois do ofício, deveria se fazer a Procissão do Enterro - hoje feita pela Ordem Terceira do Carmo -, ficando o Senhor exposto no túmulo, na Igreja da Sé, até o Domingo de Páscoa, também iluminado todo o tempo e não sendo exposto nas demais igrejas. Não havendo missa durante os dias da Semana Santa, se guardavam âmbulas com hóstias para socorrer os enfermos. Mesmo quando o Santíssimo era exposto, se fazia essa reserva, guardando as partículas atrás da custódia, para socorrer, eventualmente, aqueles que estavam em perigo de morte. Eram os únicos dias em que o Santíssimo ficava exposto fora do sacrário. (CONSTITUIÇÕES..., 1719)

O Concílio Tridentino recomendava a procissão em honra do Santíssimo Sacramento da Eucaristia pelos caminhos e lugares públicos. Na Bahia, as Constituições mandavam que a procissão saísse da Sé pela manhã, percorrendo as ruas e lugares "que deviam estar limpos e ornados com ramos, e flores, e as janelas, e paredes consertadas, e armadas com sedas, panos, alcatifas, tapeçarias, quadros, imagens de santos, e outras pinturas honestas". ${ }^{79}$ Os homens que estivessem nas janelas, "ou sentados em cadeiras de espaldas, com a cabeça cuberta", de imediato deveriam se colocar de joelhos. (CONSTITUIÇÕES..., 1853, p. 193-195) A Câmara ornava sua fachada com armações arquitetônicas efêmeras, do gênero das decorações das festividades triunfais europeias.

O Santíssimo Sacramento da Eucaristia ${ }^{80}$ era considerado, na ordem, o terceiro dos Sacramentos, mas "nas excelências o primeiro, e na perfeição o último, consubstanciado na matéria do pão de trigo, e vinho de vide, e no cálice do vinho se há também lançar uma pouca d'água como Cristo o fez, e a sua Igreja católica o determina". (CONSTITUIÇÕES..., 1853, p. 35) ${ }^{81}$

Destinava-se o sacrário como seu receptáculo. Localizado sempre nas paróquias, segundo o novo estilo romano, no "altar maior, ou em outro, se o houver mais acomodado para o culto de tão Divino Sacramento", sendo dourado por fora e "muito melhor se também o forem por dentro", ou forrado de cetim,

\footnotetext{
79 Isso explica a persistência, em algumas cidades da Bahia, e fora dela, do uso desse tipo de ornamentação, substituída, em alguns casos, por tapetes de flores.

80 Cf. Concílio Tridentino, sessão XIII, cap. I a IV. (REYCEND, 1786, p. 97)

81 Cf. Concílio Tridentino, sessão XXII, cap. 7. (REYCEND, 1786)
} 
damasco, veludo carmesim ou, ao menos, de tafetá da mesma cor, formava um cofre bem-acomodado para "ali ser encerrado Jesus Cristo Nosso Senhor". ${ }^{82} \mathrm{Na}$ impossibilidade, se reservava, em seu lugar, "alguma âmbula de prata dourada por dentro; e por fora estará a Sagrada Hóstia e as partículas que parecerem bastantes, que hão de ser renovadas ao menos cada quinze dias, em corporais de fino linho, ou de holanda muito limpos". (CONSTITUIÇÕES..., 1719, p. 46) Para levar o Sacramento aos enfermos, deveria haver outra âmbula de prata, com o mesmo tipo de cobertura dourada, por dentro e por fora.

Ambos, sacrário ou cofre e âmbula, ocupavam o lugar sobre uma pedra d'Ara, e o cofre fechado, com chave, diferente daquela do sacrário, ficando este receptáculo sempre trancado. Ambas as chaves eram douradas, uma sempre em poder do pároco, mantidas separadas de outras chaves, nunca entregues a leigos. Fora do cofre e sacrário, o Santíssimo só poderia ser exposto numa custódia. Não tomando todos os cuidados impostos, o pároco era ameaçado de ser "gravemente castigado". (CONSTITUIÇÕES..., 1719, 1588) Estando o Santíssimo Sacramento exposto, ou presente no sacrário, se mantinha um lampadário com chama acesa. O combustível utilizado poderia ser o resto dos "Santos Óleos" velhos, que eram substituídos por novos na Quinta-feira Santa, "[...] antes se queimarão, deixando-se nas alampadas do Santíssimo Sacramento, ou nas pias batismais". (CONSTITUIÇÕES..., 1719, p. 111) Os lampadários constituíam verdadeiras obras de arte em prata, barrocas ou rococós - como testemunha, aquele doado pelo capitão Antônio André Torres, em 1753, para a Igreja de São Francisco, onde se conserva até hoje. ${ }^{83}$

A cerimônia, como o transporte do viático para os doentes, exigia frascos e equipamentos, geralmente de prata, que enriqueciam as igrejas com alfaias bem-compostas, muitas dessas peças feitas por prateiros da própria cidade ou, na segunda metade do século XVIII, vindas do Porto, depois da proibição do exercício dos ourives do ouro e da prata no período pombalino. Preferencialmente, o sacerdote deveria rezar missa para consagrar o Santíssimo Sacramento. Isso só se daria em igreja, ermida ou oratório, mesmo um doméstico, com aprovação da Arquidiocese. Só em última instância o celebrante poderia utilizar um altar portátil. (CONSTITUIÇÕES..., 1853) ${ }^{84}$

82 A mesma exigência é encontrada nas Constituições do Algarve, de 1554, referindo-se à necessidade dos moradores em oferecerem um sacrário, com caixa, forrada de veludo ou cetim - e não de prata, por causa de furtos -, e dentro da caixa, a pedra d'Ara e corporais limpos, além de três hóstias, que eram renovadas a cada oito dias. Ver Constituições do Porto (1585, p. 26).

83 O capitão manteve um acordo com os religiosos, permanecendo o lampadário como sendo de sua propriedade. Foi uma das fórmulas encontradas pelos franciscanos para não quebrar seus votos de pobreza. (FLEXOR; FRAGOSO, 2009)

84 Ver Constituições do Porto (1585, p. 22-25v). 
Ao levar o Santíssimo Sacramento para administrar aos enfermos, o religioso sinalizava a saída, com o sino maior da igreja, e seguia tangendo uma campainha, pelas ruas, para que a população o acompanhasse. A casa do enfermo era, então, preparada com uma mesa segura, coberta com toalhas lavadas e com duas velas acesas. A âmbula era colocada sobre essa mesa. Seguia-se todo o cerimonial, segundo o ritual romano, todo ele descrito minuciosamente pelas Constituições baianas, indicando a melhor forma de administrar o viático. (CONSTITUIÇÕES..., 1719)

Os Santos Óleos, para a Extrema Unção, eram conduzidos numa âmbula. Se o caminho fosse longo, ao pároco era permitido levá-la numa sacola, pendurada ao pescoço. Como sempre, seguindo o ritual romano, acompanhado pela cruz da igreja, levada por clérigo ou leigo, e a caldeira de água benta, rezando um psamo próprio. Chegando à casa do enfermo, procedia conforme o ritual destinado ao Santíssimo Sacramento, acima descrito. Acrescia a aplicação dos Santos Óleos, fazendo cinco unções, segundo o ritual costumeiro, nos olhos, orelhas, nariz, boca e mãos e, ainda, no peito e nas costas, se fosse homem. (CONSTITUIÇÕES..., 1719)

Além dos "caixões e almarios" já referidos, vários móveis leigos foram admitidos no recinto das igrejas e conventos, porém, alguns móveis sacros eram indispensáveis, como o caso dos confessionários, móvel no qual os fiéis pediam a remissão de seus pecados, atendendo ao segundo Sacramento da Igreja Católica Romana. Era ordenado que todas as igrejas paroquiais, onde havia confessores ou curas de almas, tivessem certo número de confessionários nos espaços mais públicos e visíveis. As mulheres tinham preferência nos confessionários, podendo os homens ser confessados fora deles. No caso de acúmulo de pessoas, os homens poderiam confessar-se em qualquer parte do recinto da igreja. Só em tempo de peste ou doenças contagiosas, aos penitentes - e aos enfermos - era permitido se confessar fora do recinto da igreja. (CONSTITUIÇÕES..., 1719) Exemplares de confessionários barroco e rococó podem ser encontrados no Convento de São Francisco e Igreja da Abadia de São Bento, respectivamente.

Esse uso do confessionário já estava estipulado desde o século XVI em Portugal. As Constituições do Porto (1585, p. 20) descreviam como e onde deveriam estar os confessionários, bem

[...] feitos de modo que o sacerdote possa estar assentado de uma parte, e o penitente posto de joelhos da outra, ficando entre ambos um repartimento de madeira ou grade ou ralo, para que somente se possam secretamente ouvir nos quais se ouvirão as confissões de quaisquer penitentes, especialmente as das mulheres e não fora do corpo da igreja. 
A absolvição reservada de certos pecados - como feitiçaria, furto de pertences da igreja que pesassem mais de um marco de prata, ou qualquer coisa pertencente ao altar, ou de quantia de prata ou de ouro - estava a cargo dos superiores do bispado ou arcebispado. O não pagamento dos dízimos e furtos de pertences alheios fazia parte, também, das absolvições reservadas. (CONSTITUIÇÕES..., 1719) Entre os pecados que mereceram constituições específicas, encontram-se a heresia, judaísmo, blasfêmia, feitiçaria, superstições, sortes, agouros, pacto com o demônio, cartas de tocar e de palavras, bebidas amatórias, alcoviteria, rapto, estupro, alcouce (prostíbulo), homicídio, ferimento, injúria, furto, tabolagem (vício de jogo), sacrilégilo e simonia.

O pecado de simonia era considerado como crime detestável, "pestifero vício" e enorme pecado, sujeito a "gravíssimas penas", inovadas pelo Sagrado Concílio Tridentino e pela extravagante dos papas Santo Pio V, Paulo II e Bonifácio VIII. Dependendo do tipo de simonia, os autores eram castigados rigorosamente. Consistia na "malícia, e deformidade da simonia em dar, ou receber as coisas espirituais, ou anexas a elas não de graça, mas por dinheiro, ou outra coisa temporal". (CONSTITUIÇÕES..., 1719, p. 341) Mereciam castigo do pecado de sacrilégio ou simonia aqueles que furtassem cálices, custódias, lampadários, castiçais ou outros objetos dedicados ao culto Divino. Receberiam a excomunhão maior, penas pecuniárias e degredo. Intimamente ligado ao Sacramento da Confissão, estava o da Comunhão (CONSTITUIÇÕES..., 1719), que eram interdependentes.

Pode-se argumentar que as Constituições não foram totalmente adotadas. É um estudo a ser desenvolvido, a longuíssimo prazo, considerando-se que elas consagravam usos antigos e inovaram outros, como o próprio Concílio de Trento havia feito. Em relação às representações artísticas, encontram-se as mesmas características, cujos testemunhos estão presentes nas diversas igrejas para provar a sua aplicação.

Por outro lado, é preciso lembrar que os dogmas e práticas cristãos passaram a ser aceitos pela população baiana sem muitas discussões. Desde os princípios dos seiscentos, o mundo católico estava inquieto com as catástrofes, epidemias, milenarismos, os horrores do pecado e atormentados pela angústia da salvação. A presença dos jesuítas - que tiveram papel preponderante durante a realização do Concílio, em Trento - já tinha trazido para o Brasil os novos comportamentos, e eles prepararam o caminho para a cristianização dos índios. Também não foi sem objetivos que os reis ibéricos receberam os títulos de "Sua Majestade Fidelíssima", o português, e "Sua Majestade Católica", o castelhano, além do Padroado, como instrumentos de garantia da imposição do cristianismo romano nas suas conquistas. Nesse clima, a preparação para a aceitação pacífica foi feita pela Inquisição - tendo suporte nas Constituições dos diferentes 
bispados e arcebispados portugueses, além do reforço dado pelas disposições da Mesa de Consciência e Ordens -, que complementava as Ordenações Filipinas. Acresciam-se as ameaças prometidas nos compromissos das diversas irmandades, punindo quem não aparecesse aos atos públicos, não cumprisse com os deveres impostos, como confissão e comunhão anualmente, ou não se comportasse devidamente. Desse conjunto de formas de vigilância, surgiram institucionalmente os atos de acusarem-se uns aos outros. Os autos das Inquisições dão testemunhos disso.

Além das penas pecuniárias, de prisão, excomunhão, ${ }^{85}$ as Constituições prometiam severos castigos a quem blasfemasse contra Cristo e sua Mãe, como o degredo. E sendo plebeu, por não ter como pagar a pena pecuniária, pela "primeira vez, estará um dia inteiro em corpo com as mãos atadas, e com uma mordaça na boca à porta da Igreja da parte de fora; pela segunda, será açoitado sem efusão de sangue; e na terceira, será mais gravemente castigado, e condenado ao degredo para galés" (CONSTITUIÇÕES..., 1853, p. 312-313), pelo tempo que parecesse. E os religiosos seriam punidos com a perda das dignidades e prisão.

Castigavam, ainda, pelo não cumprimento do estabelecido, espiritual ou materialmente, e a fiscalização era feita pelo meirinho geral da Justiça Eclesiástica, a quem cabiam as denúncias. Nas paróquias, seriam seus próprios meirinhos, e onde não os havia, eram pessoas votadas pela freguesia. As acusações eram levadas ao provisor ou visitadores, aplicando-se, então, os castigos, se condenados. Dependendo da infração, eram castigados não só com penas do Direito eclesiástico, mas também com penas corporais e pecuniárias, e os reincidentes seriam degregados para algum lugar da África ou galés.

Uma parte das penas pecuniárias ia para o meirinho e, em muitos casos, para os acusadores. Além dos visitadores, comissários, meirinhos, entre outros, existia também uma Companhia Militar dos Familiares do Santo Ofício, como, por exemplo, é mostrado no documento (ARQUIVO HISTÓRICO ULTRAMARINO, [ca.1750]), sem data, existente na Bahia, dos meados do século XVIII, que contava com um capitão da companhia, tenente, alferes, sargento, porta bandeira, furriel, quatro cabos de esquadras, quatro aspençadas, 56 soldados fardados e armados, 15 voluntários, providos em vários postos do Regimento dos Úteis, promotor, dois escrivães, tesoureiro, almoxarife, dois moedeiros, sem contar 11 familiares já incapazes e doentes.

Em compensação, ofereciam prêmios, como, além da salvação eterna, o meio de alcançá-la ainda na terra, através de indulgências para quem, por exemplo,

85 A excomunhão atingia tanto religiosos quanto leigos e era a "espada espiritual da Igreja, e o nervo da eclesiástica disciplina”, na qual se firmava a autoridade dos prelados eclesiásticos e, por meio dela, obrigava a Igreja seus súditos à obediência. As excomunhões, chamadas de Bula da Companhia do Senhor, publicadas pelos Papas na $5^{\text {a }}$ Feira-Santa, tinham diversos graus. (CONSTITUIÇÕES..., 1719, p. 408) 
participasse das procissões de Corpus Christi, que as teria entre 100 e 600 anos. (CONSTITUIÇÕES..., 1719, 1853) Para outros atos, eram dadas até as indulgências plenárias.

Castigos ou prêmios, vida santa na terra e promessa de santidade no céu, sem passar pelo purgatório, eram artifícios para a imposição dos ditames reformistas do Concílio de Trento, ou da Contrarreforma Católica, que, se não fossem obedecidos através de atitudes e comportamentos, gerariam a opressão do Santo Ofício da Inquisição. Como era um movimento de enfrentamento a uma divisão radical de cristãos, a Igreja Romana impôs rigorosamente sua vontade, obedecida por seus seguidores, sob a vigilância do Rei e dos bispos e arcebispos, e, aos poucos, pela própria população.

Foi uma empreitada longa, desde o Concílio Tridentino, ele próprio longo (1545-1563), até alcançar as conquistas ibéricas, que, muitas já descobertas e povoadas, mereciam cuidado especial por parte das metrópoles, dadas as condições ultramarinas e sua organização social e religiosa. Desde a realização do evento de Trento, coincidentemente, se dava e divulgava o estilo barroco na Península Itálica, a partir de Roma, que colocava em prática as determinações conciliares. O barroco se estendeu para o mundo ibérico com Sua Majestade Fidelíssima e Sua Majestade Católica, leais representantes de Deus e do Papa, que continuaram a imposição das Constituições em suas conquistas, a partir dos meados do século XVI.

Diversas Constituições surgiram, então, no território luso, obedecendo, a pedido do Rei, às novas normas da Igreja Católica Romana. Cada bispado ou arcebispado publicou suas Constituições, semelhantes entre si, e adotaram o programa barroco contrarreformista romano das novas igrejas. As Constituições Primeiras do Arcebispado da Bahia regularam, sobretudo, mais comportamentos e ações e impuseram mais atitudes do que regras de construção, de elaboração de obras de pintura, escultura, de ourivesaria, mobiliário etc. Mesmo assim, credita-se a elas o programa das artes sacras na Bahia e no Brasil, porque a prática portuguesa trazia seus conhecimentos, a partir da aceitação dos modelos italianos em Portugal e, em sequência das visitações de D. Sebastião Monteiro da Vide, impuseram o programa, subliminarmente colocado nas normas constitucionais do Arcebispado da Bahia.

\section{Referências}

ALVES, M. Convento do desterro. Salvador: Prefeitura do Salvador, 1950. (Pequeno Guia das Igrejas da Bahia, n. 5).

AMARAL JÚNIOR, R. Emblemática mariana no Convento de São Francisco de Salvador, Bahia, e seus modelos europeus. Revista Lumenet et Virtus: revista de cultura e imagem, São Paulo, v. 1, n. 3, dez. 2010. Disponível em: <www.jackbran.com.br/ 
lumen_et_virtus/ numero3/artigos/ emblematica_mariana_no_Convento_de_São_ Francisco_de_Salvador>.Acesso em: 5 fev. 2014.

ARQUIVO HISTÓRICO ULTRAMARINO. Documentos avulso. Lisboa, [ca.1750]. (Documento n. 8911).

BENCÍ, J. Economia christaã dos senhores do governo dos escravos: deduzida das palavras do capitulo trinta e três do ecclesiastico: panis, e disciplina, e opus servo: reduzida a quatro discursos morais pelo padre Jorge Benci de Arimino, da Companhia de Jesu, Missionário da Província da Bahia e offerecida a Alteza Real do Sereniss. Granduque de Toscana pelo Padre Antonio Maria Bonucci da mesma Companhia. Roma: Officina de Antonio de Rossina, 1705.

BLUTEAU, R. Vocabulário português e latino... Coimbra: No Collégio das Artes da Companhia de Jesus, 1712. v. 2.

BLUTEAU, R. Vocabulário português e latino... Coimbra: No Collégio das Artes da Companhia de Jesus, 1722. v. 7.

CAMPOS, J. da S. Procissões tradicionais da Bahia. ARQUIVO PUBLICO DO ESTADO DA BAHIA. Annaes do Archivo Publico do estado da Babia. Bahia, 1941. v. 27.

CONSTITUIÇÕES do Arcebispado de Lixboa. Lisboa: Germam Galharde, 1537.

CONSTITUIÇÕES do Arcebispado de Éuora nouamente feitas por mandado do illustrissimo \& reverendíssimo señor do Ioam de Mello arcebispo do dito arcebispado. Euora: Andre de Burgos, 1565.

CONSTITUIÇÕES do Bispado do Algarve. Lisboa: Germão Galhar, 1554.

CONSTITUIÇÕES do Arcebispado de Lisboa assi as antigas como as extrauagantesprimeyras e segundas. Agora nouamente impressas por mandado do Ilustrissimo \& Reuerendissimo Senhor dõ Migel de Castro Arcebispo de Lisboa. Lisboa: Belchior Rodrigues, 1588.

CONSTITUIÇÕES primeyras do Arcebispado da Bahia feytas, \& ordenadas pelo Illustrissimo e Reuerendissimo Sor D. Sebastião Monteyro da Vide, Arcebispo do Arcebispado, \& do Conselho de Sua Magestade, propostas e acceytas em o Sinodo Diocesano que o dito Senhor celebrou em 12 de junho do anno de 1707. Lisboa Occidental: na Officina de Paschoal da Sylva, Impressor de Sua Majestade, 1719.

CONSTITUIÇÕES primeiras do Arcebispado da Bahia feitas, e ordenadas pelo Illustríssimo e Reverendíssimo D. Sebastião Monteiro da Vide, 5o Arcebispo do dito Arcebispado, e do Conselho de Sua Magestade; propostas e aceitas em o Synodo Diocesano, que o dito Senhor celebrou em 12 de Junho do anno de 1707. São Paulo: Typographia 2 de dezembro, 1853.

CONSTITUIÇÕES Synodaes do Bispado de Coimbra feitas \& ordenadas em synodo pelo Illustrissimo Sõr Dom Affonso de CastelBrãco Bispo de Coimbra, Cõde de Arganildel Rey N. S. \&c e por seu mandado impressas. Coimbra: Antonio de Mariz, 1591.

CONSTITUIÇÕES Synodaes do Bispado do Porto, ordenadas pelo muytoIllustre \& Reuerendissimo Senhor Dom Frey Marcos de Lisboa Bispo do dito Bispado \&c. - 
Agora nouamente acrecentadas com o Estilo da Iustiça. Coimbra: Antonio de Mariz: á custa de Giraldo Mendez, liureiro, 1585.

DELUMEAU, J. La reforma. Barcelona: Labor, 1973. (Nueva Clio. La historia y sus problemas)

FERREIRA-ALVES, N. M. A arte da talha no Porto na época barroca: artistas e clientela, materiais e técnica. Porto: Arquivo Histórico: Câmara Municipal do Porto, 1989. v. 1.

FLEXOR, M. H. O. Autorias e atribuições: a escultura na Bahia dos séculos XVII e XIX. Mvseu, Porto, v. 7, p. 175-215, 1998.

FLEXOR, M. H. O. Imagens de roca e de vestir na Bahia. Revista Ohun, Salvador, ano 2, n. 2, out. 2005. Disponível em http: <//www.revistaohun.ufba.br/pdf/Maria_Helena. pdf>. Acesso em: 10 jan. 2014.

FLEXOR, M. H. O. Mobiliário baiano. Brasília, DF: IPHAN, 2009. (Referência, 3).

FLEXOR, M. H.O. Nouvelaperçu sur la sculpture baroque brésilienne. In: BRÉSIL Baroque: entre cielet terre. Paris: Union Latine, 1999a. v. 2. p. 77-82.

FLEXOR, M. H. Os oficiais mecânicos em Salvador. Salvador: Departamento de Cultura da Prefeitura Municipal do Salvador, 1974.

FLEXOR, M. H.O. A religiosidade popular e a imaginária na Bahia do século XVIII. In: COLÓQUIO LUSO-BRASILEIRO DE HISTÓRIA DA ARTE, 3., 1997, Évora. Actas... Évora: Universidade de Évora, 1997.

FLEXOR, M. H. O. Revisitando a escultura barroca brasileira. In: BRASIL barroco: entre céu e terra. Paris: União Latina, 1999b. v. 1, p. 69-83.

FLEXOR, M. H. O.; FRAGOSO, H. (Org.). Igreja e convento de São Francisco da Babia. Rio de Janeiro: Versal, 2009.

FONSECA, C. D. Freguesias e capelas: instituição e provimento de igrejas em Minas Gerais. In: FEITKER, B.; SOUZA, E. S. (Org.). A igreja no Brasil: normas e práticas durante a vigência das constituições primeiras do arcebispado da Bahia. São Paulo: UNIFESP, 2011. p. 425-452.

JABOATAM, A. de S. M. Novo Orbe SeraficoBrasilico ou chronica dos frades menores da Província do Brasil. Rio de Janeiro: Typographia Brasiliense de Maximiliano Gomes Ribeiro, 1858-1862. $3 \mathrm{v}$.

MARTINS, F. S. Normas artísticas das Constituições Sinodais de D. Frei Marcos de Lisboa. In: FREI Marcos de Lisboa: cronista franciscano e bispo do Porto. Porto: Universidade do Porto, Faculdade de Letras, 2002. p. 297-309. Disponível em: < http:/ / hal.handle.net/10216/9040>. Acesso em: 10 jan. 2014.

OT'T, C. A pintura na Bahia, 1549-1850. In: ALVES, M. et al. Historia das artes na cidade do Salvador. Salvador: Prefeitura Municipal do Salvador, 1967, p. 69-108. (Evolução Histórica da Cidade do Salvador, n. 4). 
PORTUGAL. Biblioteca Nacional da Ajuda. Certificado do Reitor do Colégio dos Jesuitas da Babia: sobre as relíquias existentes no santuário do mesmo colégio. Transcrição do documento existente na Biblioteca da Ajuda . Lisboa, 1719. (Pasta 52-X-2, n. 76).

REGIMENTO do Auditorio Ecclesiastico do Arcebispado da Bahia, Metropolitano do Brasil, e da sua Relação, e Officiaes da Justiça Ecclesiastica, e mais cousas que tocão ao bom Governo do dito Arcebispado, ordenado pelo Illustrissimo Senhor D. Sebastião Monteiro da Vide, 5o Arcebispo da Bahia, e do Conselho de Sua Magestade (1704). São Paulo: Typographia 2 de dezembro, 1853.

REVISTA DO INSTITUTO GEOGRÁFICO E HISTÓRICO DA BAHIA. Salvador, 1948-1949.

REYCEND, J. B. O sacrosanto, e ecumenico Concílio de Trento em latim, portuguez dedica e consagra aos excell[entissimo]. e ver. senhores Arcebispos e Bispos da Igreja Lusitana. 2. ed. Lisboa: Officina Patriarc[a] de Francisco Luiz Ameno, 1786. 2 t.

ROCHA, J. M. da. Dirigismo na produção da imaginária religiosa nos séculos XVIXVIII: as Constituições sinodais. Mvsev, Porto, n. 5, p. 187-202, 1996.

SANTA MARIA, A. Santuario Mariano e história das imagens milagrosas de Nossa Senhora e milagrosamente manifestadas \& apparecidas em o Arcebispado da Bahia, em graça dos pregadores \& de todos os devotos da Virgem Maria Nossa Senhora. Revista do Instituto Geográfico e Histórico da Babia, salvador, v. 74, 1947.

SINZIG, P. Maravilhas da religião e da arte na igreja e no convento de São Francisco da Baia. Revista do Instituto Histórico e Geographico Brasileiro, Rio de Janeiro, v. 165, n. 1, p. 1-359, 1933.

SOLORZANO Y PEREYRA, J. De la recedencia del Consejo de Índias sobre el de Flandes:politica indiana sacada en lengua castellana de los dos tomos del Derecho y gobierno municipal de las Índias Occidentales. Madrid, 1629. t. 1.

SOLORZANO Y PEREYRA, J. De la recedencia del Consejo de Índias sobre el de Flandes:politica indiana sacada en lengua castellana de los dos tomos del Derecho y gobierno municipal de las Índias Occidentales. Madrid, 1639. t. 2.

SOLÓRZANO Y PEREYRA, J. Política indiana (sacada en lengua castellana de los dos tomos del Derecho y gobierno municipal de las Índias Occidentales. Madrid, 1996. t 3.

WIKIPÈDIA. Carlo Saraceni: Mort de laVierge.jpg, [S. 1.], 2009. Disponível em <http:// commons.wikimedia.org/wiki/File:Carlo_Saraceni_-_Mort_de_la_Vierge.jpg >. Acesso em: 2 abr. 2014

WIKIPÈDIA. La morte dela Vergine.jpg. [S. 1.], 2011. Disponível em: < http://commons. wikimedia.org/wiki/File:Caravaggio_-_La_Morte_della_Vergine.jpg>. Acesso em: 2 abr. 2014. 